Portland State University

PDXScholar

7-9-1997

\title{
Ovarian Steroid Regulation of Tryptophan Hydroxylase Enzyme Level in the Midbrain Raphe in Ovariectomized Guinea Pigs
}

Zhidong Lu

Portland State University

Follow this and additional works at: https://pdxscholar.library.pdx.edu/open_access_etds

Part of the Biology Commons

Let us know how access to this document benefits you.

\section{Recommended Citation}

Lu, Zhidong, "Ovarian Steroid Regulation of Tryptophan Hydroxylase Enzyme Level in the Midbrain Raphe in Ovariectomized Guinea Pigs" (1997). Dissertations and Theses. Paper 5320.

https://doi.org/10.15760/etd.7193

This Thesis is brought to you for free and open access. It has been accepted for inclusion in Dissertations and Theses by an authorized administrator of PDXScholar. Please contact us if we can make this document more accessible: pdxscholar@pdx.edu. 


\section{THESIS APPROVAL}

The abstract and thesis of Zhidong Lu for the Master of Science in Biology were presented July 9,1997, and accepted by the thesis committee and the department.

COMMITTEE APPROVALS:

Leonard Simpson, Chair
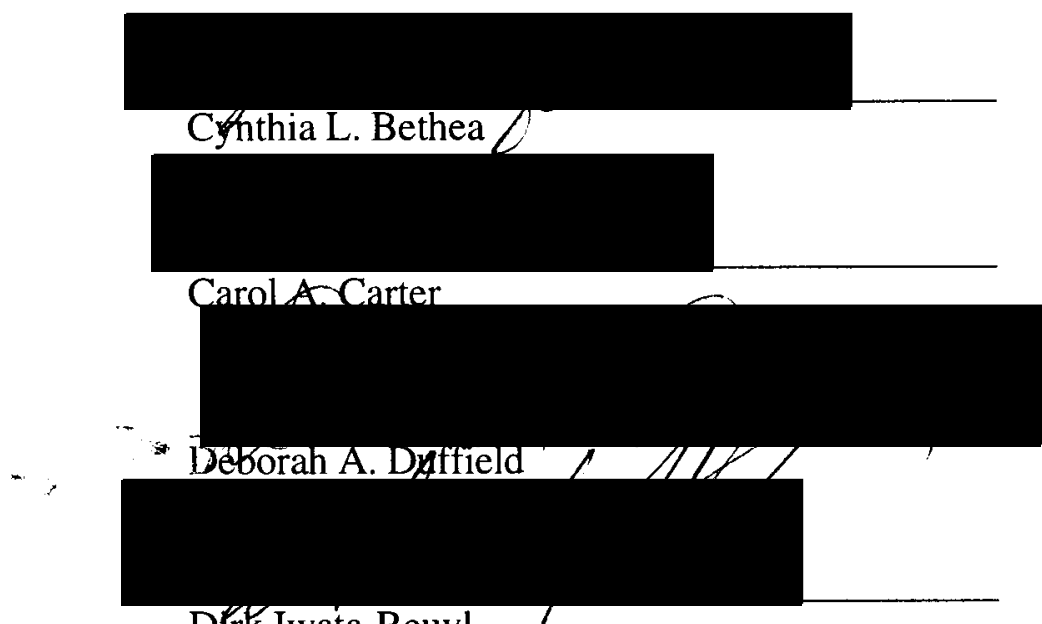

Drrk Iwata-Reuyl

Representative of the Office of the Graduate Studies

DEPARTMENTAL APPROVAL :

Leonard Simpson, Chair

Department of Biology

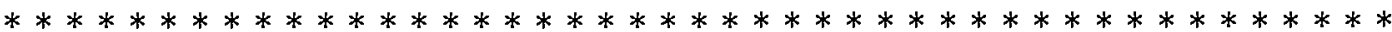

ACCEPTED FOR PORTLAXXD STATE UNIVERSITY BY THE LIBRARY

by

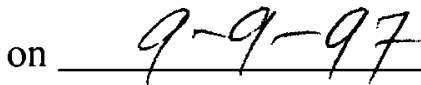




\begin{abstract}
An abstract of the thesis of Zhidong Lu for the Master of Science in Biology presented on July 9, 1997.
\end{abstract}

Title: Ovarian steroid regulation of tryptophan hydroxylase enzyme level in the midbrain raphe in ovariectomized guinea pigs.

Progesterone stimulates prolactin secretion in estrogen (estradiol-17- $\beta$ )primed monkeys and guinea pigs. It is hypothesized that the serotonin neural system plays a pivotol role in mediating the effect of progesterone on prolactin secretion. Indeed, progesterone, but not estrogen, increases serotonin levels in the midbrain raphe in guinea pigs. However, estrogen alone stimulates gene expression of the rate-limiting enzyme for serotonin synthesis, tryptophan hydroxylase (TPH), and progesterone supplement to the estrogen regimen has no additive effect, as indicated by TPH mRNA levels in monkeys. The discrepancy between ovarian steroid effects on the TPH mRNA level and the serotonin level might be due to actions of progesterone on post-transcripitonal processing of the TPH gene. In this experiment, TPH protein levels were measured in the midbrain raphe in guinea pigs. Guinea pigs were ovariectomized (OVX; $n=5$ ), estrogen-treated ( $28 d ; n=6$ ), and estrogen plus progesterone-treated (14 d of estrogen and 14 day of estrogen plus progesterone; $n=5)$. Western analysis by chemiluminescence with densitometric analysis was performed to detect and measure TPH protein levels. Hypothalamic levels of neurotransmitters were also measured with high performance liquid chromatography. The results showed that estrogen increased the TPH protein level 
significantly compared to the OVX group $(\mathrm{p}<0.05)$. TPH protein level in the estrogen plus progesterone-treated group was also significantly higher than in the OVX group $(\mathrm{p}<0.05)$. However, there was no difference between estrogen- and estrogen plus progesterone-treated guinea pigs. The hypothalamic 5-HT level was significantly increased by estrogen plus progesterone treatment $(\mathrm{p}<0.05)$, but not by estrogen alone. Thus, there continues to be a discrepancy between ovarian steroid effects on the mass of TPH enzyme and on the serotonin level. Progesterone increased the ratio of dopamine/homovanillic acid, suggesting that progesterone might decrease monoamine oxidase, the degradation enzyme for both dopamine and serotonin. In summary, progestrone did not increase prolactin secretion in estrogenprimed guinea pigs by regulating the post-transcriptional processing of the TPH gene. It is possible that progesterone increases serotonin by increasing the activity of TPH. 


\section{OVARIAN STEROID REGULATION OF TRYPTOPHAN HYDROXYLASE ENZYME LEVEL IN THE MIDBRAIN RAPHE OF OVARIECTOMIZED GUINEA PIGS}

by

ZHIDONG LU

A thesis submitted in partial fulfillment of the requirements for the degree of

\section{MASTER OF SCIENCE}

in

BIOLOGY

Portland State University

1997 


\section{ACKNOWLEDGMENTS}

This work was done in Dr. Cynthia L. Bethea's laboratory at Oregon Regional Primate Research Center. I am grateful for all that Dr. Bethea has taught me. She set an example for me of how to think like an scientist. She has been very generous with her time and encouragement. She made my learning experience here very enjoyable.

Tremendous support was also received from Dr. Leonard Simpson at Portland State University. I could not forget what the other members on my committee, Drs. Carol A. Carter, Deborah A. Duffield, and Dirk Iwata-Reuyl had demonstrated to me about how to be a researcher. I also thank Ms. Andrea A. Widmann, Drs. Melanine Pecins-Thompson and William E. Schutzer for their modeling roles. 
TABLE OF CONTENTS

ACKNOWLEDGMENTS

LIST OF FIGURES

LIST OF TABLES vi

LIST OF ABBREATIONS vii

1. INTRODUCTION 1

2. REVIEW OF LITERATURE 3

2.1 Anatomy of Serotonin Neurons 3

2.2 Innervations and Projections of Serotonin Neurons 3

2.3 Release of Serotonin . 5

2.4 Functions fo Serotonin 6

2.5 Effects of Steroids on Serotonin 6

2.5.1 Corticosteroids 7

2.5.2 Gonadal Steroids 7

2.6 Role of Serotonin in Prolactin Secretion 8

2.7 Guinea Pig Model 9

2.7.1 Guinea Pig Physiology 9

2.7.2 Previous Reports on Steroid Regulation of 10

$\begin{array}{ll}2.8 \text { Statement of Purpose } & 10\end{array}$

3. MATERIALS ANS METHODS 12

3.1 Animals and Experimental Groups $\quad 12$

$\begin{array}{ll}3.2 \text { Surgery and Treatments } & 12\end{array}$

$\begin{array}{ll}3.3 \text { Midbrain Harvest } & 13\end{array}$

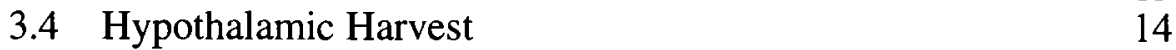

3.5 Midbrain TPH Western Analysis $\quad 15$

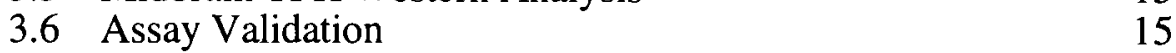

3.7 Densitometric analysis of Western Blotting Results 16

3.8 HPLC for Monoamines 16

$\begin{array}{ll}3.9 \text { Protein Assay } & 17\end{array}$

3.10 Estrogen and Progesterone RIA $\quad 17$

$\begin{array}{ll}3.11 \text { Statistical Analysis } & 17\end{array}$

$\begin{array}{ll}3.12 \text { Vaginal Smears } & 18\end{array}$

4. RESULTS 19

4.1 Assay Validation for Quantitative Analysis of TPH Enzyme 19 
4.2 Western Analysis of TPH Enzyme in Steroid-treated 19 Guinea Pigs

4.3 Midbrain Raphe TPH Content 20

4.4 Assay Validation for HPLC Measurement of Biogenic 20 Amines in the Hypothalamus

4.5 Concentrations of Biogenic Amines in the Hypothalamus 21

4.6 Pituitary Wet Weight 21

4.7 Steroid Hormones Levels $\quad 22$

4.8 Vaginal Smears 22

4.9 Brain Section Wet Weight and Protein Content 22

5. DISCUSSION 38

6. CONCLUSION 46

$\begin{array}{ll}\text { 7. REFERENCES } & 47\end{array}$ 


\section{LIST OF FIGURES}

Figure

Page

1. Assay validation for measurement of TPH protein.

2. Western analysis results.

3. Densitometric analysis of the TPH protein levels.

4. Reading the density of TPH bands.

5. TPH enzyme levels.

6. HPLC for biogenic amines.

7. Hypothalamic serotonin and 5-HIAA levels.

8. Hypothalamic dopamine and homvanillic acid levels.

9. Ratios of serotonin over 5-HIAA and dopamine over homovanillic acid.

10. Pituitary wet weight in steroid-treated guinea pigs. 33

11. Vaginal smears of steroid-treated guinea pigs. 


\section{LIST OF TABLES}

Table

Page

1. Pituitary wet weight after $28 \mathrm{~d}$ of steroid treatment. 35

2. Serum estrogen and progesterone levels after $28 \mathrm{~d}$ of 36 steroid treatment.

3. Wet weight and protein cotent of raphe and hypothalamus dissections 


\section{LIST OF ABBREVIATIONS}

\begin{tabular}{ll}
\hline 5-HIAA & 5-hydroxyindoleacetic acid \\
ANOVA & analysis of variance \\
cAMP & cyclic adenosine 3 ', ' $^{\text {-monophosphate }}$ \\
CNS & central nervous system \\
DMH & dorsal medial hypothalamus \\
GABA & $\gamma$-amino butyric acid \\
HPLC & high-performance liquid chromatography \\
OVX & ovariectomized \\
MAO & monoamine oxidase \\
MBH & mediobasal hypothalamus \\
ME & median eminence \\
PACAP & pituitary adenylate cyclase activating \\
PCPA & polypeptide \\
PIF & p-chorophenylalanine \\
PRF & prolactin-inhibiting factor \\
RIA & prolactin-releasing factor \\
SCN & radioimmunoassay \\
SEM & suprachiasmatic nucleus \\
SERT & standard error of the mean \\
TH & serotonin reuptake transporter \\
TIDA & tyrosine hydroxylase \\
TPH & tuberoinfindibular dopamine \\
TRH & tryptophan hydroxylase \\
VIP & thyrotropin-releasing hormone \\
\hline & vasoactive intestinal peptide \\
\hline
\end{tabular}




\section{INTRODUCTION}

Prolactin is a versatile hormone [1-4]. The number of the physiological functions of prolactin exceeds 80 across the vertebrate phyla [5]. The preparation, maintenance, and secretory activity of the mammary gland during lactation is controlled by prolactin [2]. Therefore, prolactin is critical to the offspring of mammalian species for survival. Also, prolactin plays a role in other physiological processes including stimulation of the immune system $[6,7]$ and responses to stress $[8,9]$.

Prolactin is primarily synthesized by lactotropes in the anterior pituitary. Pituitary prolactin secretion is represented by serum prolactin levels. Prolactin secretion fluctuates with ovarian steroids during the menstrual cycle and pregnancy [10-13]. Lactotrope hypertrophy and pituitary enlargement occur at the end of human and non-human primate gestation [14]. These observations suggest that ovarian hormones, estrogen (estradiol-17- $\beta$ ) and progesterone, regulate prolactin secretion. Indeed, progesterone has a stimulatory effect on prolactin secretion in estrogen-primed monkeys [15] and guinea pigs [16]. Intriguingly, neither progesterone nor estrogen alone have this effect [15-18].

The target cells of steroid hormones are defined by the presence of nuclear receptors for the cognate hormones. The observation that pituitary lactotropes lack progestin receptors [19-21] directed investigators to search for progesterone target neurons in central nervous system (CNS). Among the neuroendocrine systems in the hypothalamus and midbrain, serotonin neurons have been of special interest. In rodents, serotonin enhances prolactin secretion [22]. Also in rodents, progesterone increases the serotonin content of the raphe [16] as well as the 
hypothalamic serotonin turnover $[23,24]$. Double immunocytochemistry analysis revealed that serotonin neurons in the dorsal and ventral raphe in the midbrain contain progestin receptors [25], indicating that serotonin neurons are a target system of progesterone. Furthermore, progestin receptors in this area are maintained with estrogen plus progesterone treatment in a manner consistent with the observation that progesterone induces prolactin secretion [26]. Hence, serotonin may transduce the action of progesterone on prolactin secretion. Therefore, it is of interest to know what are the cellular and molecular mechanisms of the action of progesterone in serotonin neurons. 


\section{REVIEW OF LITERATURE}

\subsection{Anatomy of Serotonin Neurons}

Serotonergic neurons are a population of morphologically heterogeneous cells located mainly in the brainstem [27-37]. These neurons are multipolar cells with different sizes and orientations in different locations in the brainstem. The raphe nuclei of the brainstem are the sites for the cell bodies of the majority of serotonin neurons. Whereas the cells located in the midline regions of the raphe nuclei are small to medium-size, and are oriented with most of their dendrites along the mid-sagittal plane, cells distant from the midline are larger than those in the midline regions [38]. Besides the raphe nuclei, the reticular formation is another location containing serotonergic neurons. The reticular formation is peripheral to the raphe nuclei, occupying the rostral and caudal ventrolateral medulla. The two prominent nuclei in the midbrain raphe are the dorsal raphe nucleus, which is located in the ventral part of the periventricular gray matter of the midbrain, and the median raphe nucleus, which is on the midline and adjacent to the outside of the midline in the brainstem $[39,40]$.

\subsection{Innervations and Projections of Serotonin Neurons}

The raphe nuclei receive input from dopaminergic neurons in the substantia nigra and ventral tegmental area, acetylcholinergic neurons in the superior vestibular nucleus, norepinephrinergic neurons in locus coeruleus, and epinephrinergic neurons in the nucleus prepositus hypoglossi and the nucleus of the solitary tract [4I]. There are also afferent innervations of serotonin neurons from the hypothalamus, thalamus, and limbic forebrain structures. 
The high degree of polarity of the serotonergic projections is a unique feature of the serotonergic system [42-44]. The serotonin cells consist of two distinct groups, a caudal group in the medulla oblongata and in the caudal half of the pons, and a rostral group in the midbrain and rostral pons. Both the dorsal raphe nucleus and the median raphe nucleus belong to the rostral serotonergic system. Serotonin neurons send axons from the rostral group towards the forebrain and from the caudal system to the structures of the brainstem and to the spinal cord.

The ascending projections of the rostral serotonergic system are very extensive and contain many collaterals innervating diverse regions of the cerebral cortex, basal ganglia, limbic system and diencephlon [31,37,42,45-49]. Two main pathways for these rostral projections are the dorsal periventricular path and the ventral tegmental radiations. Both pathways converge in the caudal hypothalamus where they join the medial forebrain bundle. From the medial forebrain bundle, distinct sets of axons from different raphe nuclei diverge to form different subpathways which they follow to their target areas in the brain. All areas of the forebrain display specific innervations. Functionally related structures are innervated by the same set of serotonin neurons [50,51].

The hypothalamus receives extensive innervation from serotonin neurons $[52,53]$. Neurons innervating the hypothalamus are primarily from the dorsal and median raphe nuclei. The pathways of the projections of these neurons are the medial forebrain bundle, a dorsal raphe arcuate tract, and a dorsal raphe periventricular tract [53]. The arcuate nucleus has dense serotonergic innervations [27-29]. In the arcuate nucleus and in the medial zona incerta, dopamine neurons which project to the hypothalamus juxtapose with serotonin-containing fibers 
[54,55]. These serotonin and dopamine interactions support the hypothesis that serotonin plays a role in the regulation of prolactin release via inhibition of TIDA neurons [22].

\subsection{Release of Serotonin}

Serotonin neurons store serotonin in vesicles and release the neurotransmitter by exocytosis. Serotonin released into the synapse binds with specialized serotonin membrane receptors and carries out actions in target tissues. There are several mechanisms to regulate serotonin secretion and function. The initial step in the synthesis of serotonin is the facilitated transport of the amino acid L-tryptophan in dietary protein from the circulation to the brain. Clinical studies show that the availability of the amino acid transporters and the concentration of tryptophan in the blood influence serotonin content in the brain [56]. Tryptophan hydroxylase (TPH; EC 1.12.16.4) is the rate-limiting enzyme for serotonin synthesis [41]. The fluctuation of TPH content and activity should cause consequent changes in serotonin content in the brain. Second, the degradation of serotonin influences the content of serotonin in the brain. Monoamine oxidase (MAO) (EC 1.4.3.4) converts serotonin into 5-hydroxyindoleacetaldehyde, which is oxidized to form 5-hydroxyindoleacetic acid (5-HIAA), the primary metabolite of serotonin. Usually, serotonin is protected by the membranes of the storage vesicles from degradation by MAO and serotonergic neurons do not contain much MAO. However, clorgyline, an inhibitor of a type A MAO, increases serotonin levels and reduces the conversion of serotonin to 5-HIAA in the brain [57]. Third, the removal of serotonin from the synapses would affect serotonin neurotransmission. Serotonin reuptake transporters (SERT) remove serotonin from the synapse and 
terminate the activity of serotonin. Fourth, different subtypes of serotonin receptors and different densities of these subtypes mediate different effects of serotonin. Not only are the subtypes of serotonin receptors coupled to different signal transduction mechanisms, they also have different distribution patterns in the brain. Serotonin 1 A receptors down-regulate serotonin activity when they function as autoreceptors [58]. However, serotonin $1 \mathrm{~A}$ can be located post-synaptically as well.

\subsection{Functions of Serotonin}

Serotonin has many important and diverse physiological actions. Serotonin has beeen implicated in sleep and arousal states [59]. Serotonin also appears to play a role in the regulation of circadian rhythms $[60,61]$. The SCN, the biological clock nuclei, receive dense serotonin innervation from the midbrain raphe nuclei. Observations suggest serotonin inhibits food intake [62]. Serotonin deficiency has beeen related to depression and most major mood disorders [63]. Serotonin in the pineal gland is the precursor of melatonin, a hormone related to the seasonal breeding cycles of sheep and hamsters. Serotonin is also among the many neurotransmitters that participate in the hypothalamic control of the pituitary secretion, particularly in the regulation of adrenocorticotropin, growth hormone and prolactin [22].

\subsection{Effects of Steroids on Serotonin}

Some studies suggest that serotonin participates in the regulation of physiological processes that are dependent upon or sensitive to steroid hormones, such as ovulation [64], sexual behavior [65], and the response to stress [66]. 
However, information on the effects of steroids on serotonin activity is scant and the molecular mechanism for these effects are unresolved.

\subsubsection{Corticosteroids}

Stress increases the activity of the hypothalamic-pituitary-adrenal axis and causes an elevation in glucocorticoid secretion [67]. The activity of TPH, the ratelimiting enzyme in serotonin synthesis, is affected by adrenalectomy [68] and glucocorticoids [69] in rats. Adrenalectomy also decreases serotonin reuptake into hypothalamic terminal neurons. Plasma corticosterone is inversely correlated with serotonin content in the amygdala and directly correlated with hypothalamic serotonin content [70]. In the hypothalamus, adrenalectomy decreases serotonin turnover in some nuclei while the supraoptic nucleus exhibits a large increase. Corticosterone treatment partially reverses these effects [71]. Serotonin 1 receptors in the dorsal raphe but not in the median raphe are increased following adrenalectomy [72]. Corticosterone replacement reverses the effects.

\subsubsection{Gonadal Steroids}

The ovarian steroids, estrogen and progesterone, are produced in a cyclic manner throughout the estrous and menstrual cycles. Administration of estrogen and progesterone results in time-, dose- and region-specific changes in serotonin reuptake in rats[73-75]. In the dorsal raphe nucleus, estrogen in rats [76-77] and estrogen plus progesterone in guinea pigs [16] increase serotonin levels. Hypothalamic serotonin turnover increases with estrogen plus progesterone treatment, but not with estrogen alone [78,79]. In addition, progesterone partially blocks the effect of $\rho$-chorophenylalanine (PCPA), a serotonin synthesis inhibitor, 
on hypothalamic serotonin levels and an antiprogesterone reduced hypothalamic levels of 5-HIAA, a serotonin metabolite [78]. Moreover, PCPA inhibits the proestrus surge of prolactin and progesterone treatment reverses this effect [80].

Progesterone could also affect the levels of serotonin receptor expression in target neurons. Serotonin2 receptors are stimulatory, post-synaptic receptors which act through the phosphoinositol pathway $[81,82]$ whereas serotonin $1 \mathrm{~A}$ receptors may be pre- or post-synaptic [83]. As autoreceptors, serotonin 1 receptors inhibit the activity of serotonin neurons. In vivo treatment with estrogen displays a biphasic effect on the density of serotonin1 receptors in the rat brain [85]: an increase in the receptor density followed by a sudden decrease 48 hours later. Prolonged treatment with estrogen or progesterone induces a down regulation in serotonin 1 receptors, whereas the number of serotonin 2 receptor goes up $[84,85]$. Progesterone administration to estrogen-treated rats reverses the estrogen-induced increase in serotonin 2 receptors, but has no effect on the estrogen-induced reduction in serotonin 1 receptors.

\subsection{Role of Serotonin in Prolactin Secretion}

Although serotonin does not act directly at the pituitary to release prolactin [86], a pivotal role for serotonin in prolactin secretion is well-supported [22-24]. Many pharmacological studies have shown a stimulatory effect of serotonin on prolactin secretion in rodents. The serotonin precursor, 5-hydroxytryptophan, alone or with fluoxetine (a serotonin reuptake inhibitor) stimulated prolactin secretion [23]. In addition, serotonin antagonists for serotonin 1B receptors block the stimulating effects of fenfluramine, a serotonin releaser [23], or serotonin 
agonists [24] on prolactin secretion. However, the cellular and molecular action of progesterone in serotonin neurons is unknown.

\subsection{Guinea Pig Model}

The majority of the studies on the regulation of serotonin by estrogen and progesterone are performed with rats. However, rats differ significantly from primates and humans in the regulation of prolactin secretion by ovarian steroids $[13,15,87]$. Another small laboratory animal model would be beneficial to elucidate the cellular and molecular consequences of ovarian steroid actions in serotonin neurons.

\subsubsection{Guinea Pig Physiology}

Guinea pigs have a 16- to 18-day estrous cycle with the length of estrus to be $8.21 \pm 0.07$ hours [88]. Ovulation occurs approximately 10 hours following the onset of estrus and usually within 1.5 to 2 hours of the end of estrus [88-90].

Unlike rats, but similar to primates, guinea pigs exhibit prolonged function of the corpus luteum and elevated progesterone secretion after ovulation [91]. The gonadotropins, estrogen and progesterone have been examined throughout the guinea pig estrous cycle [92] and during pregnancy [91]. Also in guinea pigs, ovarian steroids regulate prolactin secretion in the same manner as ovarian steroids do in primates. That is progesterone, in addition to estrogen, but not estrogen alone, increases serum prolactin in OVX guinea pigs [16] and monkeys $[15,17,18]$. Thus, guinea pigs may provide a better model for non-human primates than rats for studies of the neural mechanism mediating the effects of ovarian steroids on serotonin and prolactin. 


\subsubsection{Previous Reports on Steroid Regulation of Serotonin and Prolactin in Guinea Pigs}

Guinea pigs were OVX, estrogen-treated (28 days) and estrogen plus progesterone-treated (14-day estrogen with 14-day estrogen plus progesterone) [16]. Serotonin was measured in the midbrain raphe area by high performance liquid chromatography (HPLC). Serum prolactin was measured with the NB2 lymphoma bioassay. Estrogen alone had little effect on serum prolactin levels, but estrogen plus progesterone significantly increased prolactin compared to the OVX controls. Serotonin levels were similar in OVX and estrogen-treated groups. Addition of progesterone to the estrogen treatment significantly increased serotonin compared to the estrogen-only treatment. Thus, the pattern of the steroid regulation of serotonin levels in midbrain raphe is consistent with that of the steroid regulation of serum prolactin in guinea pigs, which in turn, is consistent with the effect of estrogen and progesterone on prolactin secretion in monkeys. Hence, guinea pigs are an appropriate model in which to determine the mechanism by which progesterone increases serotonin in the dorsal raphe.

\subsection{Statement of Purpose}

Steroids penetrate the blood brain barrier easily and interact with nuclear receptors in target neurons $[93,94]$. The steroid hormone-receptor complexes are transcription factors for gene expression. Serotonin neurons in monkeys contain progestin receptors [25] and the expression of progestin receptors is under the regulation of estrogen and progesterone [26], indicating that progesterone acts in serotonin neurons. Pecins-Thompson et al. showed that estrogen increased TPH 
mRNA in monkeys but progesterone had no additive effect [95]. However, in guinea pigs, estrogen plus progesterone but not estrogen alone increased serotonin content in the raphe [16]. The discrepancy between TPH mRNA levels in monkeys and serotonin levels in guinea pigs suggested that pregesterone may affect posttranscriptional events to modify TPH function. It was also possible that a species difference between guinea pigs and monkeys was involved. Since previous studies had measured serotonin in the midbrain raphe in guinea pigs, this study examined the effects of estrogen and progesterone on TPH protein levels in the raphe nuclei and correlated the TPH protein concentrations in the raphe nuclei with the hypothalamic serotonin concentration in guinea pigs. 


\section{MATERIALS AND METHODS}

\subsection{Animals and Experimental Groups}

All animals were euthanized according to procedures recommended by the Panel on Euthanasia of the American Veterinary Medical Association. These experiments were approved by the Oregon Regional Primate Research Center Animal Care and Use Committee.

All animal treatments and brain tissue harvest procedures are according to the procedures by Bethea et al. [16]. Sixteen adult OVX guinea pigs were purchased from Charles River Laboratories (Wilmington, Mass., USA). Guinea pigs were housed in individual cages in a temperature- and light- $(12 \mathrm{~h}$ light/12 $\mathrm{h}$ dark) controlled room. They were fed Purina guinea pig chow, and water was available at all times. Green vegetables were supplied every other day.

\subsection{Surgery and Treatments}

Two weeks following OVX, the guinea pigs were weighed and injected with a guinea pig anesthetic consisting of $50 \mathrm{mg} / \mathrm{kg}$ ketamine $\mathrm{HCl}$ (Mallinckrodt Veterinary Inc., Mundelein, $\mathrm{L}$ ), $1 \mathrm{mg} / \mathrm{kg}$ Acepromazine Maleate (Burns Veterinary Supply, Rockville Center, NY), and 2 mg/kg Rompun (Miles Inc., Shawnee Mission, KS) for insertion of Silastic capsules $(0.5 \mathrm{~cm}$ long; inner diameter 0.062 in, outer diameter 0.125 in; Dow Corning, Midland, MI) which were either empty $(n=4)$ or filled with crystalline estradiol $(n=8 ; 1,3,5,(10)$-Estratrien-3,17- $\beta$-Diol, Steraloids, Wilton, NH). The capsule was placed in the periscapular area. Incisions were $1 \mathrm{~cm}$ long and sutured or woundclipped after Silastic capsules were placed subcutaneously. Fourteen days later, half of the estrogen-treated guinea pigs 
were sedated for insertion of Silastic capsules $(1.5 \mathrm{~cm}$ long) filled with crystalline progesterone ( $n=4 ;$ 4-pregnen-3,20 Dione, Steraloids). Fourteen days later, the animals were injected with the guinea pig anesthetic and decapitated in sets containing an OVX, an estrogen-treated, and an estrogen plus progesterone-treated animal. Vaginal smears were obtained prior to decaptation. Trunk blood was collected for determinations of serum estrogen and progesterone levels by RIA. The brains were immediately dissected. The hypothalamus and midbrain were weighed and the hypothalamic block was dropped into liquid nitrogen for later microdissection and measurement of serotonin and 5-HIAA. The raphe block was immediately homogenized for measurement of TPH enzyme. The wet weight of the pituitary was obtained following removal of the brain from the skull. The same experiments were repeated on an additional set of OVX $(n=1)$, estrogen- $(n=2)$, and estrogen plus progesterone-treated $(n=1)$ animals one month after OVX.

\subsection{Midbrain Harvest}

The pontine midbrain section (approximately $3 \mathrm{~mm}$ thick) displayed the rounded central canal on its anterior surface and the wing-shaped canal on its caudal surface. This section was microdissected immediately at necropsy and a small square piece of tissue was harvested which extended from the top of the central gray to the decussation of the cerebellar peduncles. The piece was the width of the central gray and contained the major portion of the dorsal raphe. Each piece was immediately homogenized in $250 \mathrm{ml}$ of $50 \mathrm{mM}$ Tris (pH 7.5; ICN Biomedicals, Aurora, OH) and $20 \mathrm{mM} 2-\beta$-mercaptoethanol ( Sigma Chemical Co., St. Louis, $\mathrm{MO}$ ) and centrifuged at $10,000 \mathrm{xg}$ for 2 minutes. The supernatant was removed and stored at $-80^{\circ} \mathrm{C}$ until TPH western analysis. The pellet was dissolved in 0.5 
$\mathrm{N} \mathrm{NaOH}$ by boiling for $15 \mathrm{~min}$. Protein assays were performed on both the supernatant and the dissolved pellet.

\subsection{Hypothalamic Harvest}

Hypothalamic blocks were obtained from each animal. Each block is bordered by optic chiasm, mamillary bodies, and lateral sulci. The block was wrapped in foil and dropped in liquid nitrogen at necropsy, then stored at $-80^{\circ} \mathrm{C}$ until HPLC analysis. Immediately prior to analysis, each hypothalamic block was slightly thawed and the rostral one-third of the block was dissected out and discarded. The medial part, containing the dorsal medial hypothalamus (DMH), and the mediobasal hypothalamus (MBH), was trimmed on the sides, vertical to the innermost border of the optic tract and horizontal to the caudal tip of the third ventricle. DMH contained the majority of the dorsomedial nuclei and the caudal end of the paraventricular nucleus whereas MBH contained ventromedial, ventrolateral, and arcuate nucleus. There was no left-right division of blocks.

Each piece was homogenized in $1 \mathrm{ml}$ of mobile phase (101 mM sodium acetate trihydrate, Sigma; $67 \mathrm{mM}$ citric acid monohydrate, Sigma; and 4\% Methanol, Baxter Healthcare Corporation) containing $1 \mathrm{pg} / \mathrm{ul}$ dihydroxybenzylamine internal standard. The sample was centrifuged at $10,000 \times \mathrm{g}$ for 2 minutes, and the supernatant was removed and filtered through Microcon-10 microconcentrators (Amicon Inc., BEverly, MA) for amine HPLC. The pellet was resuspended in $1 \mathrm{ml}$ of $0.5 \mathrm{~N} \mathrm{NaOH}$ to determine protein levels. Previous characterization has found that $95-98 \%$ of the total protein is precipitated by the mobile phase [16]. 


\subsection{Midbrain TPH Western Analysis}

The protein content of the raphe supernatant was determined with the BioRad protein determination reagent according to the method of Bradford [96]. Raphe extracts containing $300 \mu \mathrm{g}$ of protein were loaded on a $10 \%$ SDS polyacrylamide gel. A monkey pineal extract containing $129 \mu \mathrm{g}$ of protein was used as a positive control . Western blotting was performed according the modified procedures of Dumas et al. [97] with blotting buffer containing $25 \mathrm{mM}$ Tris base (ICN) and $192 \mathrm{mM}$ glycine (Sigma). Nitrocellulose transfer membrane was from Schleicher \& Schuell (Keene, NH). The nitrocellulose membrane was blocked with 5\% aqueous Carnation natural non fat dry milk (Nestle Food Company, Glendale, CA) for 45 minutes. Affinity purified sheep anti-TPH (Chemicon International Inc., Temecula, CA) was used at a dilution of $1 / 500$ in buffer containing $50 \mathrm{mM}$ Tris (Sigma) and $150 \mathrm{mM} \mathrm{NaCl}$ (Sigma) (pH 7.5). Rabbit antisheep antibody conjugated with horse radish peroxidase (Chemicon) was used as second antibody at a dilution of 1/7,000. TPH signal was detected by exposing the blot to chemiluminescent-sensitive film after developing with ECL detection reagents (Amersham International Plc., Buckinghamshire, England) as described by Brandon and Bethea [98]. Scientific imaging film (Eastman Kodak) was used for diagnostic developing and the exposure time was 15 minutes. For the quantitative analysis of TPH, the NIH image software program was used.

\subsection{Assay Validation}

The reliability of the quantitative analysis for TPH protein was confirmed by analyzing increasing concentrations of monkey pineal gland protein extracts and monkey raphe protein extracts. Five monkey pineals were homogenized with 0.5 
$\mathrm{ml}$ of buffer as above. The protein level was measured according to Bradford [96]. Pineal extract samples $(50 \mu \mathrm{g}, 100 \mu \mathrm{g}$, and $150 \mu \mathrm{g}$ of protein) were electrophoresed and blotted as described above and used for quantitative analysis of TPH. One monkey raphe was processed with the same method and extract samples (100 $\mu \mathrm{g}, 200 \mu \mathrm{g}$, and $300 \mu \mathrm{g}$ of protein) were electrophoresed and blotted as described above and used for quantitative analysis of TPH.

\subsection{Densitometric Analysis of Western Blotting Results}

The image of the TPH bands on the film were captured using a XC-77 CCD video camera (Sony, Towada, Japan). The pineal TPH band was copied below the TPH band from each sample. The region of interest containing the pineal band and the sample band was marked. The image analysis program scanned each lane from the top to the bottom and read the density of each band. The density of the TPH band on the film was converted to a peak. The area under each peak was calculated. The TPH band from monkey pineal extract was used as the positive control. The image analysis program used the density of the positive control band as the maximum reading on the scale for density reading.

\subsection{HPLC for Monoamines}

The content of serotonin, 5-HIAA, dopamine, and homovanillic acid in the hypothalamic block was determined by HPLC with electrochemical detection (Waters). A Keystone (Keystone SCI. INC.) catecholamine column (ODS Hupersil, $100 \times 4.4 \mathrm{~mm}, 3 \mu \mathrm{m}$ particle size ) was used with mobile phase as above (see section 2.4). The eluent was passed through an electrochemical detector (Waters 460 ) set at $+0.60 \mathrm{~V}$ and $0.2 \mathrm{nA}$. The concentration of the calibration 
standard for biogenic amines was at $5 \mathrm{pg} / \mu \mathrm{l}$. The average retention times for dopamine, 5-HIAA, homovanillic acid, and serotonin were 7.0, 9.7, 15.1, and 22.0 minutes respectively. The sensitivity of detection was $10 \mathrm{pg}$ for dopamine, 5-HIAA, and serotonin and $50 \mathrm{pg}$ for homovanillic acid. The concentrations of monoamines were quantitated by comparing the area under the peak of the unknown sample with the peak area of a standard. Standard preparations were analyzed at increasing injection volumes, and the measurement of dopamine, 5-HIAA, and serotonin was linear between 10 and $500 \mathrm{pg}$, and linear between 50 and $500 \mathrm{pg}$ for homovanillic acid. The unknown samples were assayed at $5 \mu \mathrm{l}$ for dopamine, 5-HIAA, and serotonin and at $100 \mu \mathrm{l}$ for homovanillic acid which fell within the linear range for each amine. Amine levels were normalized to nanograms per milligram protein.

\subsection{Protein Assay}

Protein content in both raphe and hyphothalamus tissues was measured according to Bradford using Bio-Rad protein determination reagent [96].

\subsection{Estrogen and Progesterone RIAs}

The estradiol-17- $\beta$ and progesterone levels were determined with RIA as described by Resko et al. $[99,100]$.

\subsection{Statistical Analysis}

Midbrain TPH protein levels, hypothalamic monoamine concentrations, pituitary wet weight, serum estrogen and progesterone, brain wet weight, and protein content were compared using analysis of variance (ANOVA) followed by 
the Student-Newman-Keuls pairwise post-hoc comparison. Data analysis was conducted using the Instat Statistic Program (GraphPad, San Diego, CA) on a Macintosh computer. A confidence level of $p<0.05$ was considered significant.

\subsection{Vaginal Smears}

Prior to necropsy, vaginal smears were obtained from all animals with saline lavage. The lavage was placed on microscope slides (Fisher Scientific, Auburn, WA). Smears were then air-dried overnight and stained with hematoxylin (Sigma) for 5 minutes. Sections were then dehydrated in a graded series of alcohol, and coverslipped with Permount. Vaginal smears from different treatment groups were compared as a confirmation of steroid treatment. 


\section{RESULTS}

\section{I Assay Validation for Quantitative Analysis of TPH Enzyme}

The densities of the TPH enzyme signals from the western analysis are positively correlated with the concentrations of the protein (Figure 1). The density (peak area) of 50,100, and $150 \mu \mathrm{g}$ of pineal TPH protein extracts was 596, 2243, and 3369 , respectively. The density (peak area) of $100,200,300 \mu \mathrm{g}$ of raphe protein extracts was 3399,5395 , and 9102 , respectively. The quantitative analysis of TPH enzyme with Western analysis and the NIH Image Analysis software was linear in the range of 50 to $300 \mu \mathrm{g}$ of protein.

\subsection{Western Analysis of TPH Enzyme in Steroid-treated Guinea Pigs}

The results of western blot analysis of the 16 guinea pigs are shown in Figure 2. The film (Panel B) was compared with the nitrocellulose membrane (Panel A) stained with 2\% Ponceau-S (Sigma), demonstrating the specificity of the western analysis. The Ponceau-S-stained nitrocellulose membrane displayed multiple protein bands. However, the affinity-purified anti-TPH antibody specifically binds to TPH enzyme. Thus, TPH signals were shown by the single band in each lane of panel B after ECL chemilumenescence. For densitometric anaylysis, the monkey pineal TPH band, as a positive control, was placed below each sample band as shown in Figure 3. The pineal band enabled the computer to accurately scale each lane the same. Two representative plots from the denstiometric analysis are shown in Figure 4. 


\subsection{Midbrain Raphe TPH Content}

The results on TPH enzyme levels are shown in Figure 5. Average TPH content (peak area \pm SEM) was $1636.40 \pm 252.66,2836.67 \pm 132.38$, and $2515.00 \pm 326.79$ for the OVX, estrogen-treated, and estrogen plus progesteronetreated groups, respectively (Fig 5.A.). TPH enzyme level (ratio of the reading from each sample band over the reading from the pineal control band \pm SEM) was $0.397 \pm 0.063,0.738 \pm 0.039$, and $0.676 \pm 0.086$ for the OVX, estrogen-treated and estrogen plus progesterone-treated guinea pigs, respectively (Figure 5.B.). In the raphe, estrogen treatment approximately doubled the TPH enzyme level $(p<0.05)$. Addition of progesterone did not change the TPH enzyme levels compared to estrogen-only treatment. However, the level of TPH enzyme in the estrogen plus progesterone-treated group remained significantly higher than that in the OVX group $(\mathrm{p}<0.05)$. Thus, TPH protein in estrogen-treated and estrogen plus progesterone-treated groups was significantly higher than that in the OVX group, but estrogen- and estrogen plus progesterone-treated groups were not different from one another.

\subsection{Assay Validation for HPLC Measurement of Biogenic Amines in the Hypothalamus}

The concentration of the standard biogenic amines for calibration was at $5.0 \mathrm{pg} / \mu \mathrm{l}$ in $0.07 \mathrm{mM}$ sodium acetate (Sigma). Volumes of the calibration solution injected in HPLC were 2, 5, 10, 50, $100 \mu 1$. The amine concentrations were converted from peak areas as shown in the chromatograms (Figure 6, A and B). Peak responses for serotonin, 5-HIAA, and dopamine were linear within the range 
of 10 and $500 \mathrm{pg}$ (Figure 6, C and D). The peak responses for homovanillic acid were linear within the range of 50 and $500 \mathrm{pg}$.

\subsection{Concentrations of Biogenic Amines in the Hypothalamus}

The average of the serotonin concentrations ( $\mathrm{ng} / \mathrm{mg}$ of protein, $\pm \mathrm{SEM}$ ) was $7.46 \pm 0.77,7.76 \pm 0.70$, and $10.08 \pm 0.50$ for the OVX, estrogen, and estrogen plus progesterone groups, respectively. Serotonin levels increased significantly in the estrogen plus progesterone-treated group compared to estrogen-treated group $(\mathrm{p}<0.05$; Figure 7.). There was no significant difference between estrogentreated group and OVX group in serotonin levels ( $\mathrm{p}>0.05$; Figure 7). 5-HIAA, dopamine, and homovanillic acid concentrations showed no differences among the OVX, estrogen, and estrogen plus progesterone groups ( $\mathrm{p}>0.05$ ) (Figure 7 and 8). However, the ratio of the concentration of dopamine over that of homovanillic acid, had a significant increase in estrogen plus progesterone-treated group compared to OVX ( $p<0.05$; Figure 9). The ratio of serotonin/5-HIAA had a moderate but statistically insignificant increase in the estrogen plus progesteronetreated group compared to estrogen-treated and OVX group.

\subsection{Pituitary Wet Weight}

The average wet weight of the pituitary in each treatment group is shown in Table 1 and Figure 10. The weight of the pituitary in the estrogen- and estrogen plus progesterone-treated groups are significantly higher than that of the OVX group $(p<0.05)$. Comparisons between the wet weight and the ratios of the wet weight to the body weight maintain the same pattern. 


\subsection{Steroid Hormone Levels}

The estrogen levels $(\mathrm{pg} / \mathrm{ml} \pm \mathrm{SEM})$ equaled $36.00 \pm 2.65$ in the OVX guinea pigs and $141.82 \pm 36.72$ in the estrogen and estrogen plus progesterone groups ( $\mathrm{p}<0.01)$. The progesterone levels $(\mathrm{ng} / \mathrm{ml} \pm \mathrm{SEM})$ averaged $0.10 \pm 0.10$, $0.05 \pm 0.03$, and $4.13 \pm 0.36$ in the OVX, estrogen, and estrogen plus progesterone groups, respectively. Progesterone levels in the estrogen plus progesterone group were significantly higher than that in the OVX and estrogen groups $(\mathrm{p}<0.001)$. The steroid replacement treatment changed the serum estrogen and progesterone levels within or close to the physiological range [92] (Table 2.)

\subsection{Vaginal Smears}

Vaginal smears were taken before necropsy to verify the efficacy of steroid implants. Representative pictures of the stained vaginal smears from OVX, estrogen, and estrogen plus progesterone groups are shown in Figure 11. The predominance of small leukocytes was the characteristic of the vaginal smears of OVX group. Large numbers of cornified squamous epithelial cells dominate the vaginal smears of estrogen-treated group. The infiltration of small leukocytes and the presence of round nucleated epithelial cells can be seen in the vaginal smears of estrogen plus progesterone-treated guinea pigs.

\subsection{Brain Section Wet Weight and Protein Content}

The wet weight of dissected hypothalamic and raphe fragments were consistent, indicating the dissection was reproducible. The total protein content in the raphe blocks and in the hypothalamic blocks had little variance among different treatment groups as well. The average weight ( $\mathrm{mg} \pm \mathrm{SEM}$ ) of the raphe sections 
did not differ significantly between treatment groups $(105.32 \pm 5.73,113.93 \pm$ 8.58 , and $102.48 \pm 3.26$ for the OVX, estrogen, and estrogen plus progesterone groups, respectively; $\mathrm{p}>0.05)$. The wet weight (mg \pm SEM) of the hypothalamic sections did not differ significantly between treatment groups (164.88 \pm 20.42 , $166.25 \pm 14.50$, and $172.40 \pm 7.89$ for the OVX, estrogen, and estrogen plus progesterone groups, respectively; $\mathrm{p}>0.05)$. The ratio of the protein content to the wet weight of each brain dissection were also consistent from group to group (Table 3). 

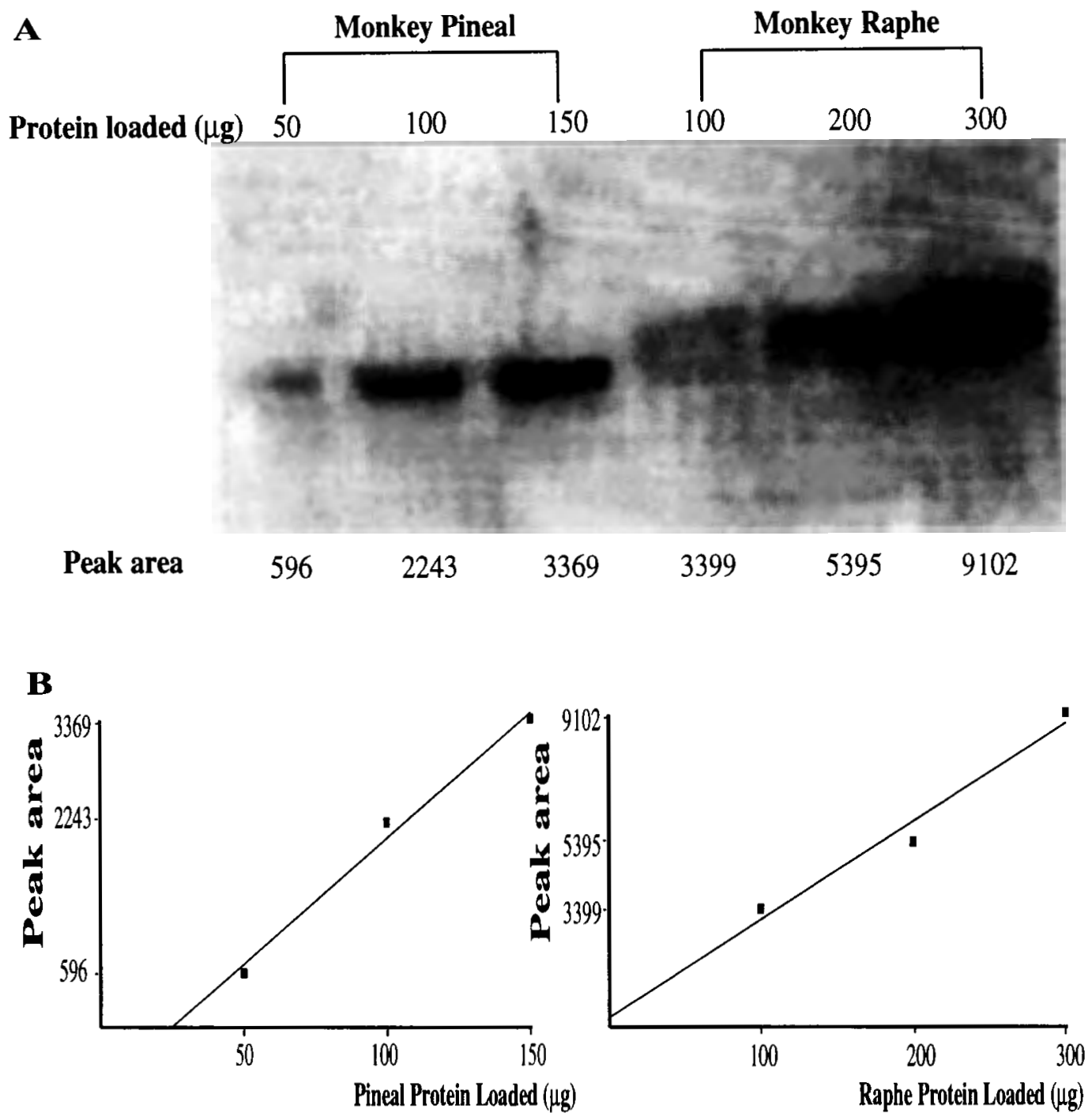

Figure 1. Assay validation for measurement of TPH protein. Increasing amounts of pineal protein extracts and raphe protein extracts were processed with Western analysis and densitometric measurement. The Western results are shown in Panel A. Note with the increasing amounts of protein (in $\mu \mathrm{g}$, shown above each lane), the density of each band increases as indicated by a peak area (numbers below each band). Panel B shows that the densitometric analysis of TPH protein is linear in the range of 50 and $300 \mu \mathrm{g}$ of protein. 
A.

B.

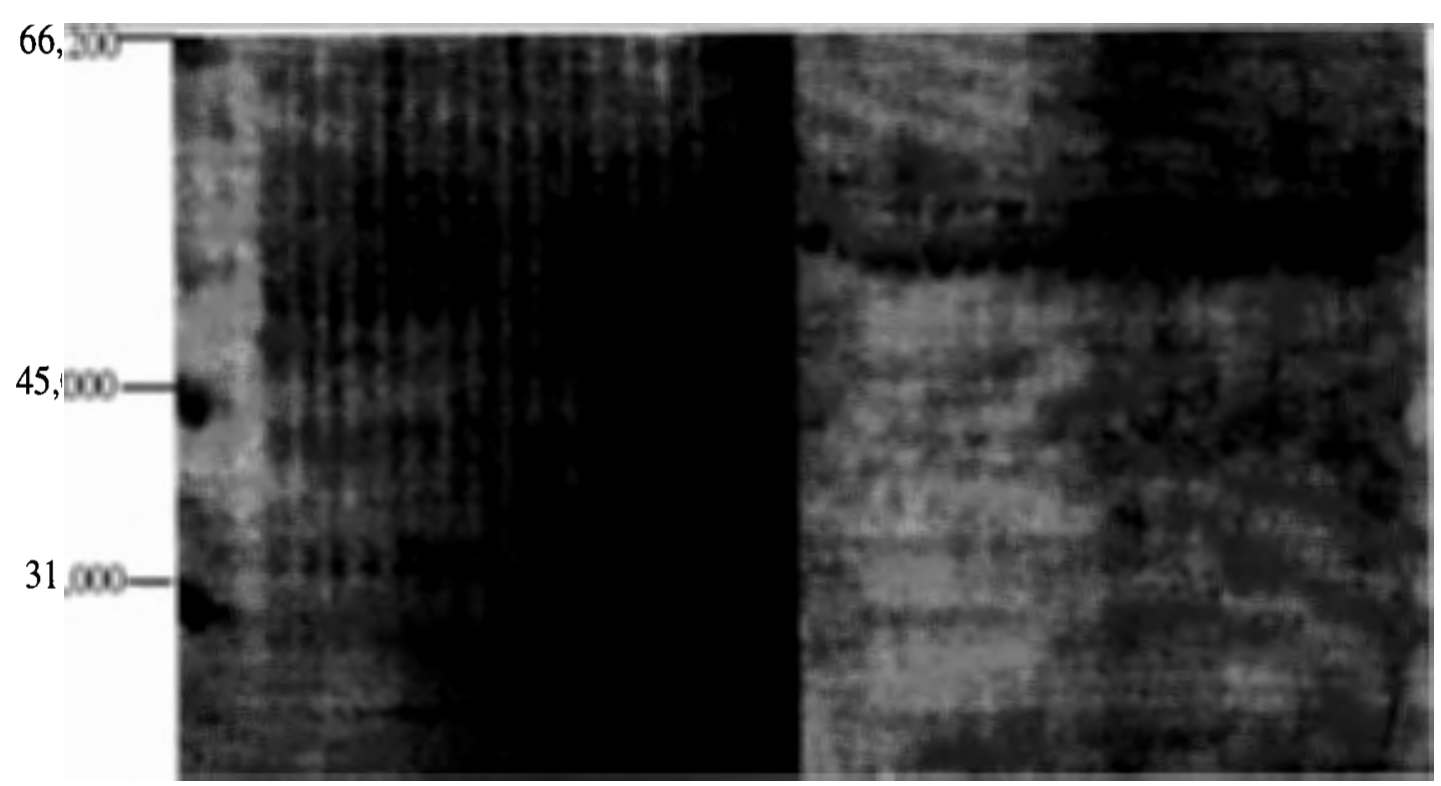

Figure 2. Western analysis results. A. Ponceau-S-stained nitrocellulose blot. B. Film of the blot after incubation with anti-TPH antibody and ECL detection. Note the multiple protein bands in each sample lane shown by Ponceau-S staining in A and the specificity for TPH protein of the western analysis shown by a strong signal band in each lane in $\mathrm{B}$. 


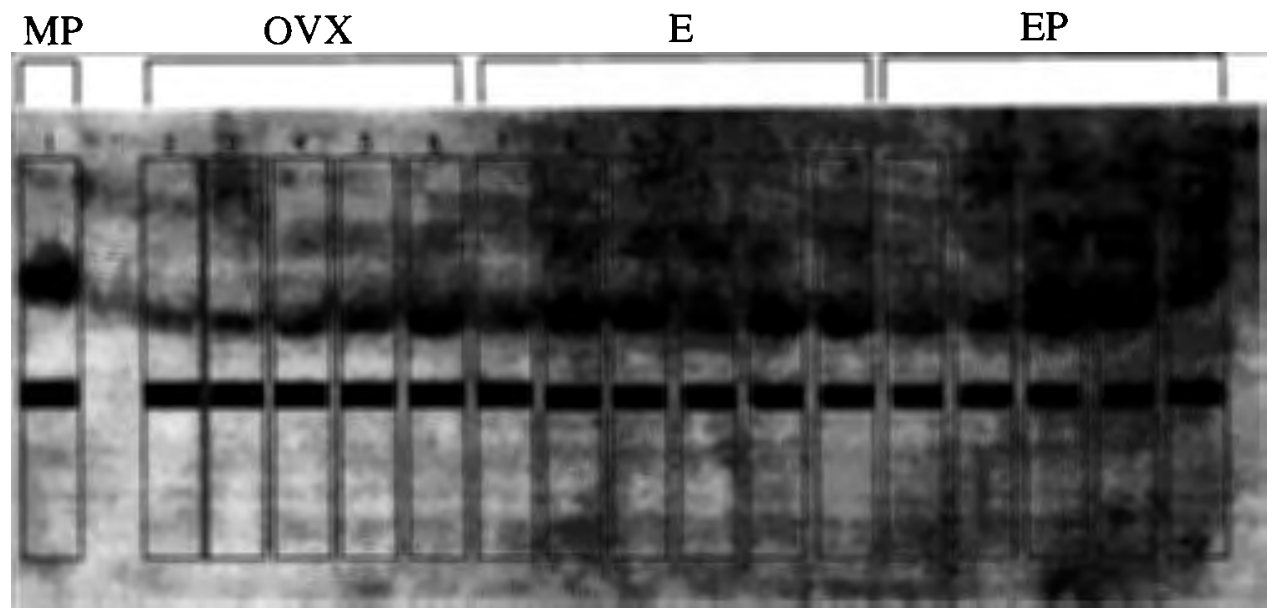

Figure 3. Densitometric analysis of the TPH protein levels. Monkey pineal (MP) TPH band (the darker rectangular square at the lower part of each lane) was copied under each sample band as a positive control. Lanes 2 through 6 represent the OVX guinea pigs $(n=5)$; lanes 7 through 12 represent the estrogen-treated group; lanes 13 through 17 represent the estrogen plus progesterone-treated group. Each labeled lane was marked as a region of interest. Densitometric analysis was achieved by scanning from the top to the bottom of each lane with the reading from the pineal band set as the maximum value on the scale of density. 
A.

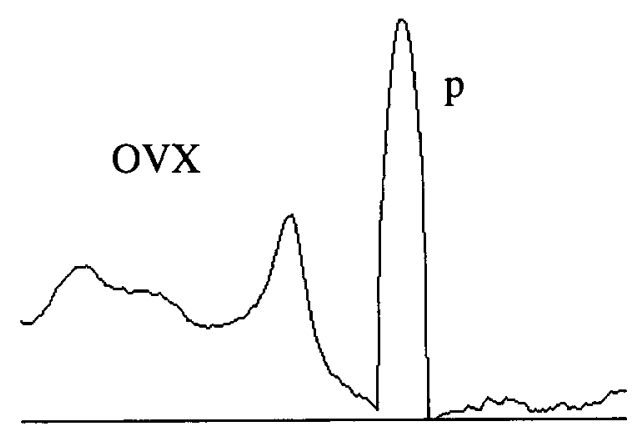

$\overline{\mathrm{C}}$.

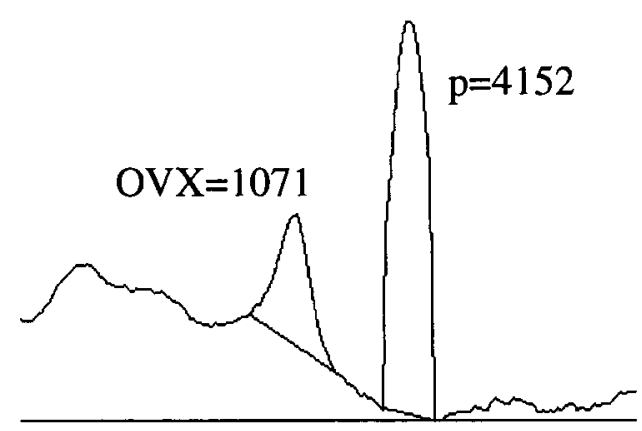

B.

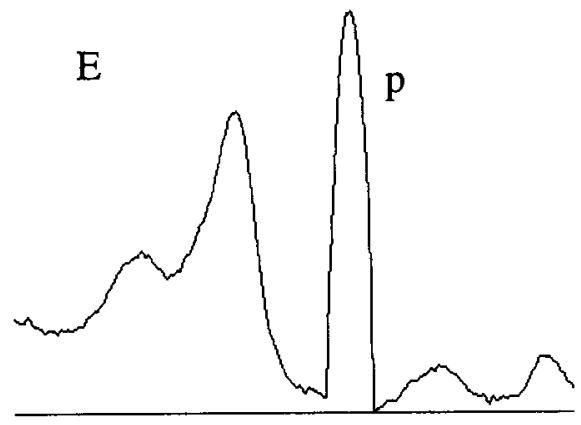

D.

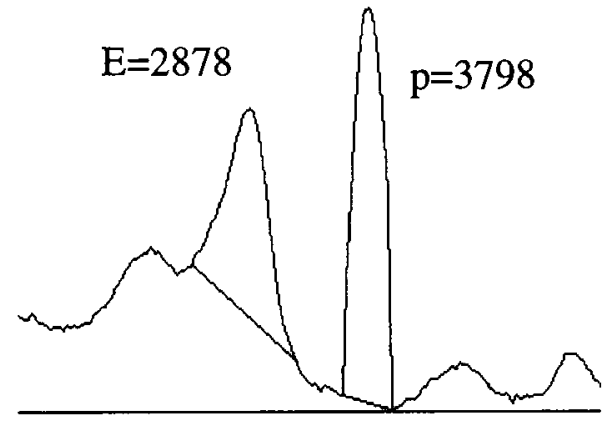

Figure 4. Reading the denstity of TPH bands. A and B are peaks from two representative TPH bands, one from an OVX guinea pig and the other from an estrogen (E)-treated guinea pig. The calculated peak areas are shown in C and D. The calculation requires sealing of the peak areas. Note the relative consistent reading obtained on the positive control. $\mathrm{p}$, the pineal TPH peak. 

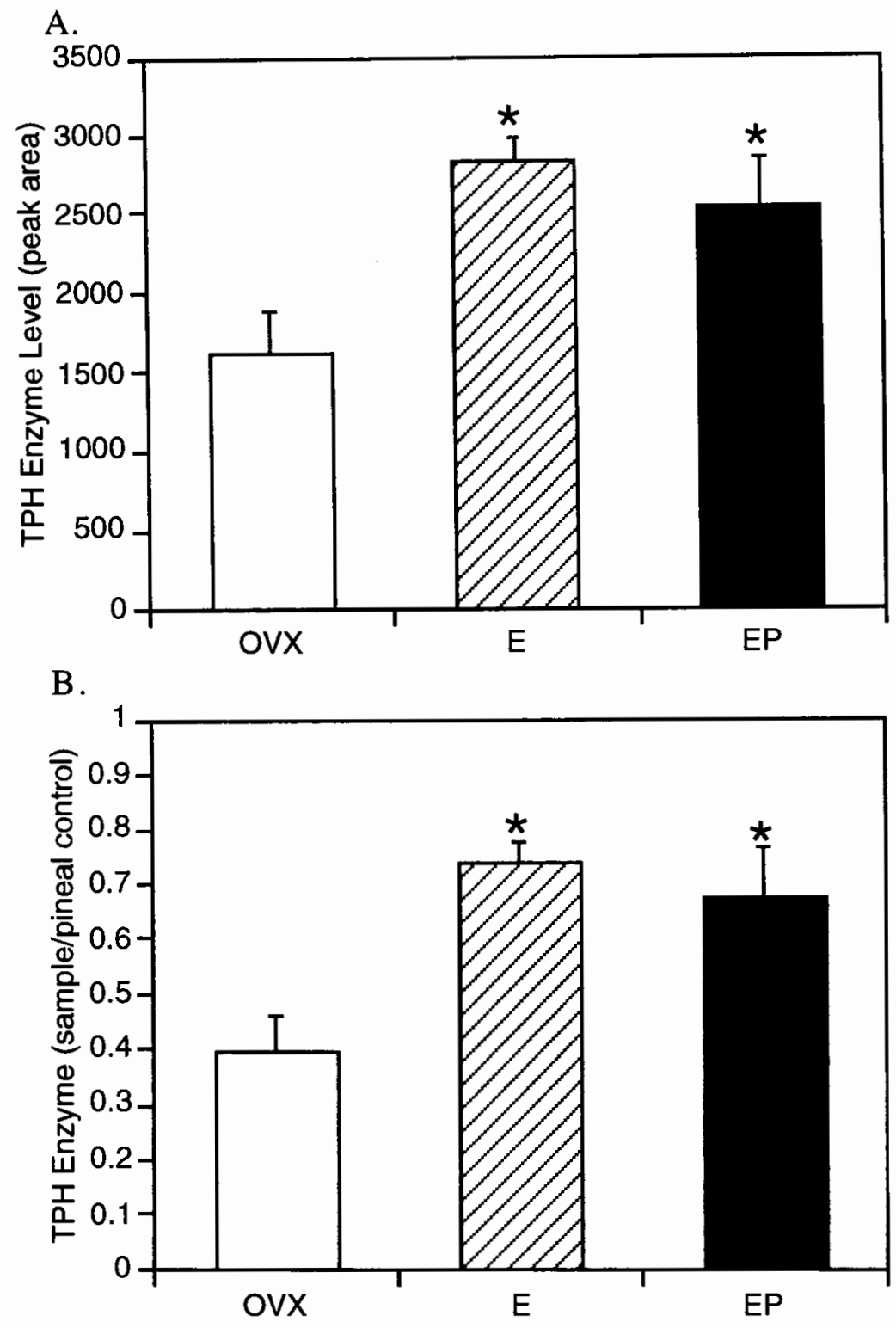

Figure 5. TPH enzyme levels. A. Average TPH enzyme levels (peak area). B. TPH enzyme (density of sample band/density of pineal control band) in the midbrain raphe. Guinea pigs were OVX, estrogen (E)-treated (28 days), and estrogen plus progesterone (EP)-treated (14-day of estrogen plus 14-day of estrogen plus progesterone) as described in Materials and Methods. TPH enzyme levels were significantly different between estrogen-treated and OVX groups. There was also a significant difference on TPH levels between estrogen plus progesterone-treated and OVX groups. Statistics was analyzed with ANOVA followed by Student-NewmannKeuls comparisons $(*, p<0.05)$. The levels of TPH enzyme in estrogen- and estrogen plus progesterone-treated groups were similar. 
A

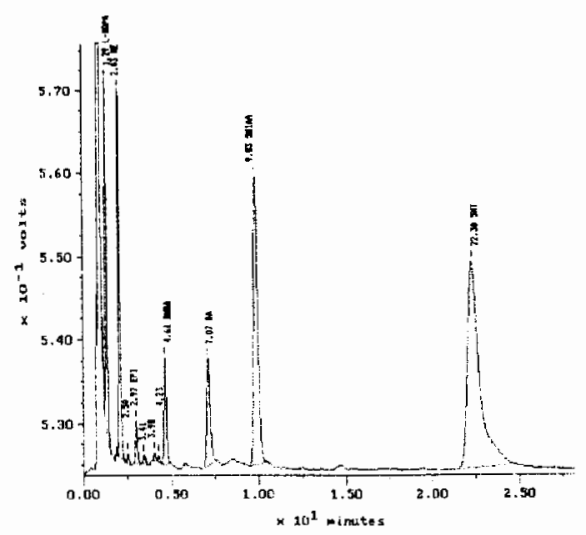

B

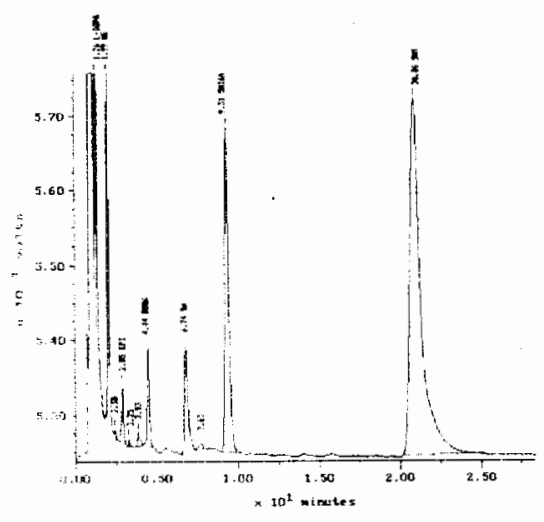

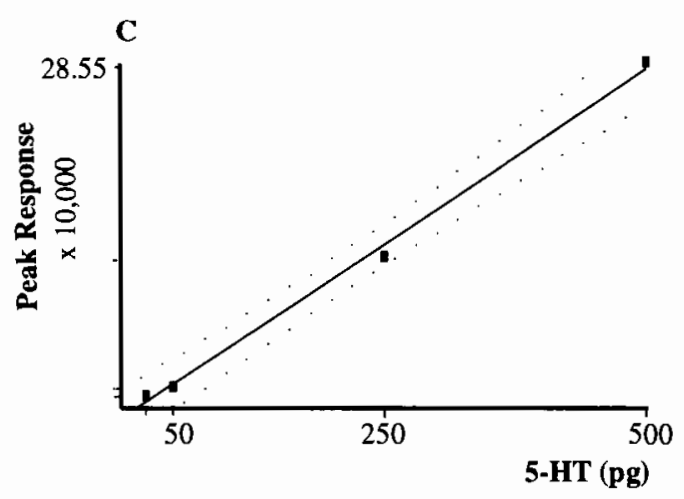

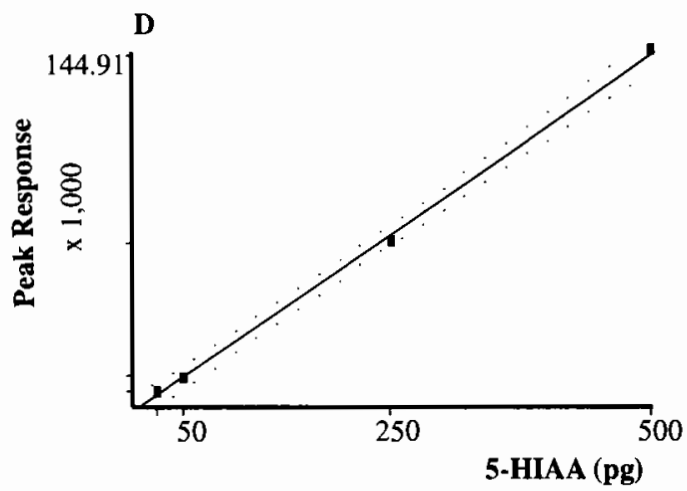

Figure 6. HPLC for biogenic amines . Two representative chromatograms:

A. OVX guinea pig. B. Estrogen plus progestin-treated guinea pig. Average retention times for dopamine, 5-HIAA, homovanillic acid, and serotonin (5-HT) were 7.0, 9.7, 15.1, and 22.0 minutes, respectively. Concentrations of biogenic amines in samples were determined by comparing the peak areas of samples with the peak areas of amine standards (not shown) on chromatograms. Amine standards for calibration ranged from 10 to $500 \mathrm{pg}$ and the peak response was linear throughout the range for serotonin (C), 5-HIAA (D), and dopamine (not shown). Peak response for homovanillic acid was linear in the range of 50 and $500 \mathrm{pg}$ (not shown). 


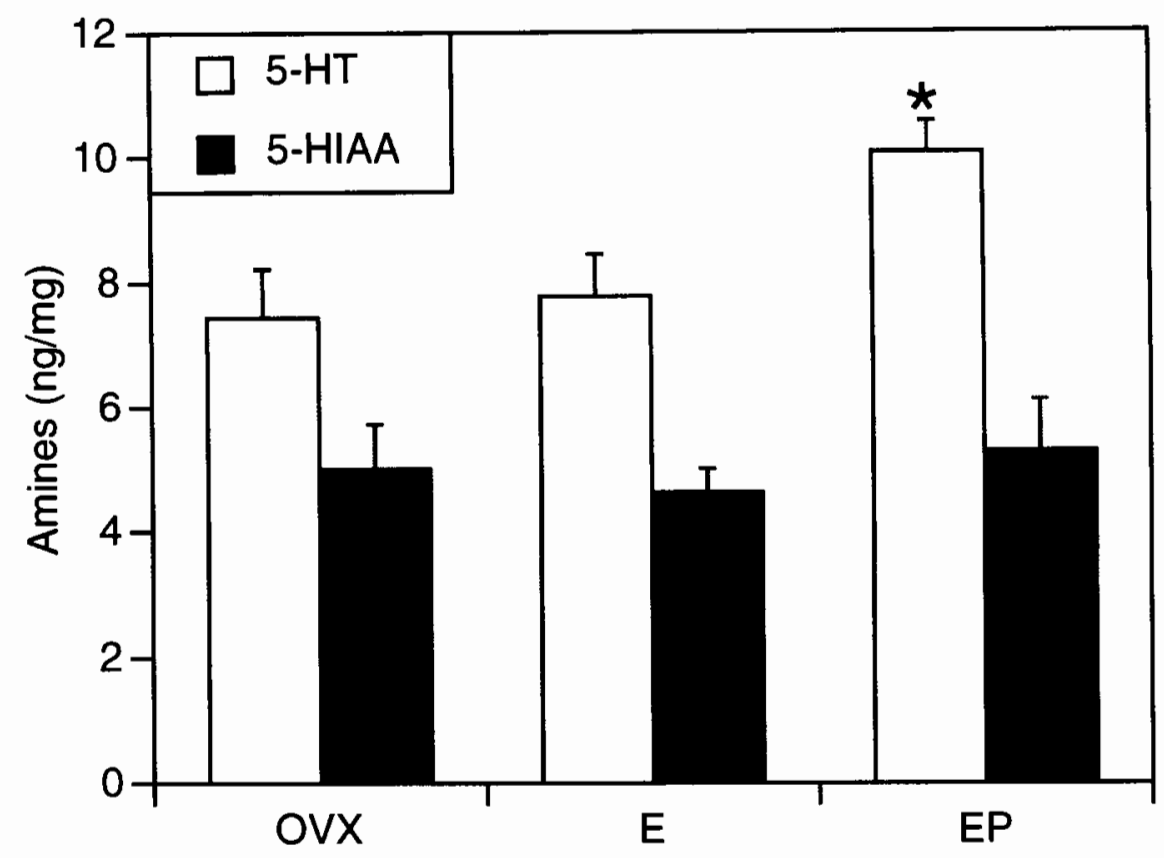

Figure 7. Hypothalamic serotonin (5-HT) and 5-HIAA levels (ng/mg of protein \pm SEM). Guinea pigs were OVX, estrogen (E)-treated (28 days), and estrogen plus progesterone (EP)-treated (14-day of estrogen and 14-day of estrogen plus progesterone). There was a significant increase in the serotonin level in estrogen plus progesterone-treated group compared to the estrogen-treated groups $\left(^{*}, \mathrm{p}<0.05\right.$; ANOVA followed by Student-Newmann-Keuls comparisons). There was no difference in serotonin levels between estrogen-treated and OVX group. 5HIAA levels did not show any differences between treatment groups. 


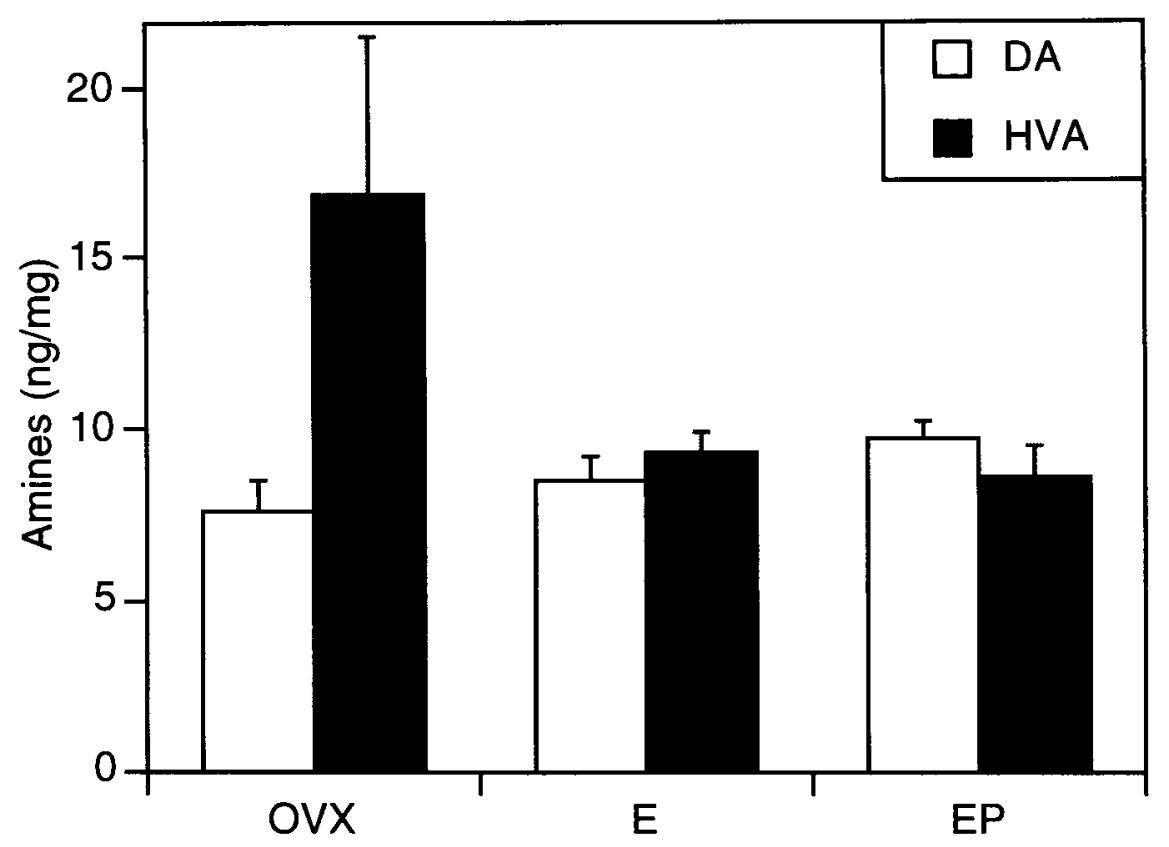

Figure 8. Hypothalamic dopamine (DA) and homovanillic acid (HVA) levels (ng/mg of protein \pm SEM). Guinea pigs were OVX, estrogen (E)-treated (28 days), and estrogen plus progesterone (EP)-treated (14-day of estrogen and 14-day of estrogen plus progesterone). There were no significant differences between treatment groups ( $>$ > 0.05; ANOVA and Student-Newmann-Keuls comparisons). 


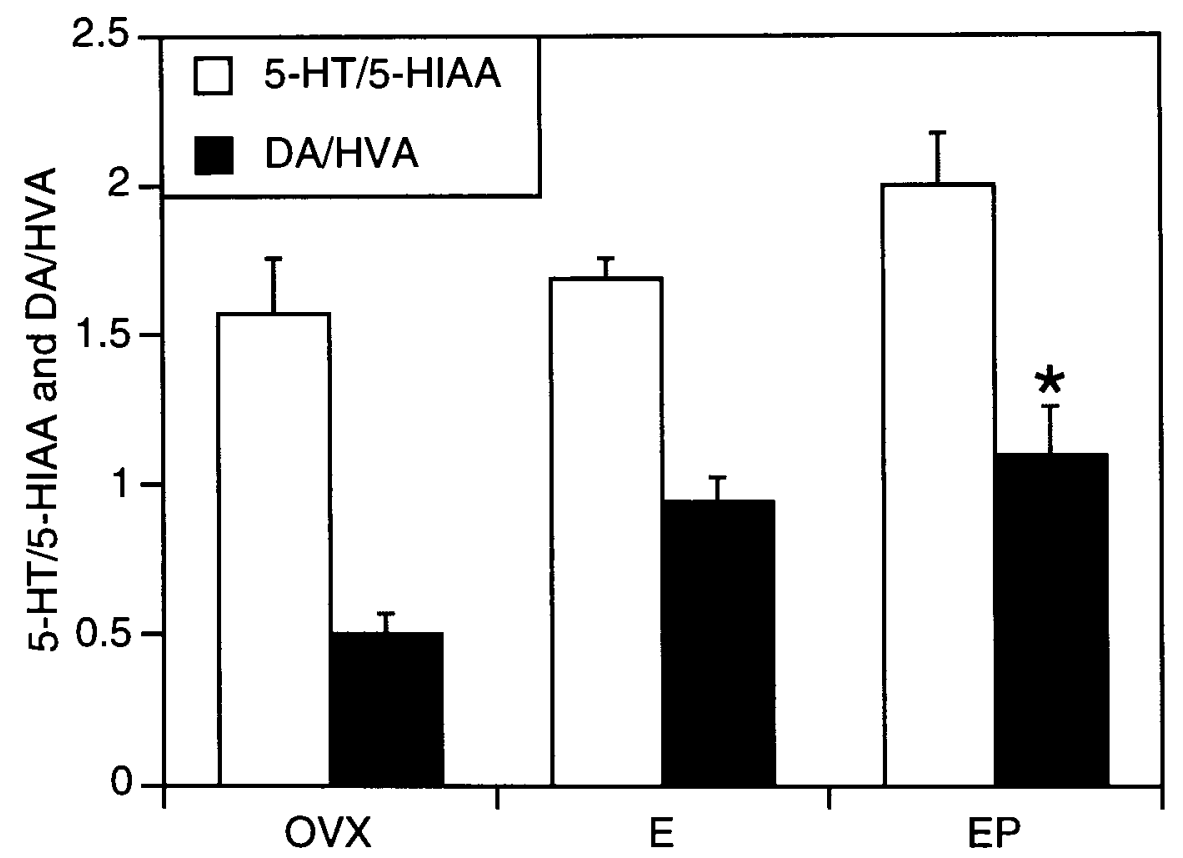

Figure 9. Ratios of serotonin over 5-HIAA (5-HT/5-HIAA) and dopamine over homovanillic acid (DA/HVA) $( \pm$ SEM). Guinea pigs were OVX, estrogen (E)-treated (28 days), and estrogen plus progesterone (EP)-treated (14-day of estrogen and 14day of estrogen plus progesterone). There was a significant increase of DA/HVA in estrogen plus progesterone-treated group versus OVX group $(*, p<0.05)$. There was no difference between estrogen-treated group and OVX group on DA/HVA. The modest increase of 5-HT/5-HIAA in estrogen plus progesterone-treated group was not statistically significant compared to estrogen-treated and OVX groups. 


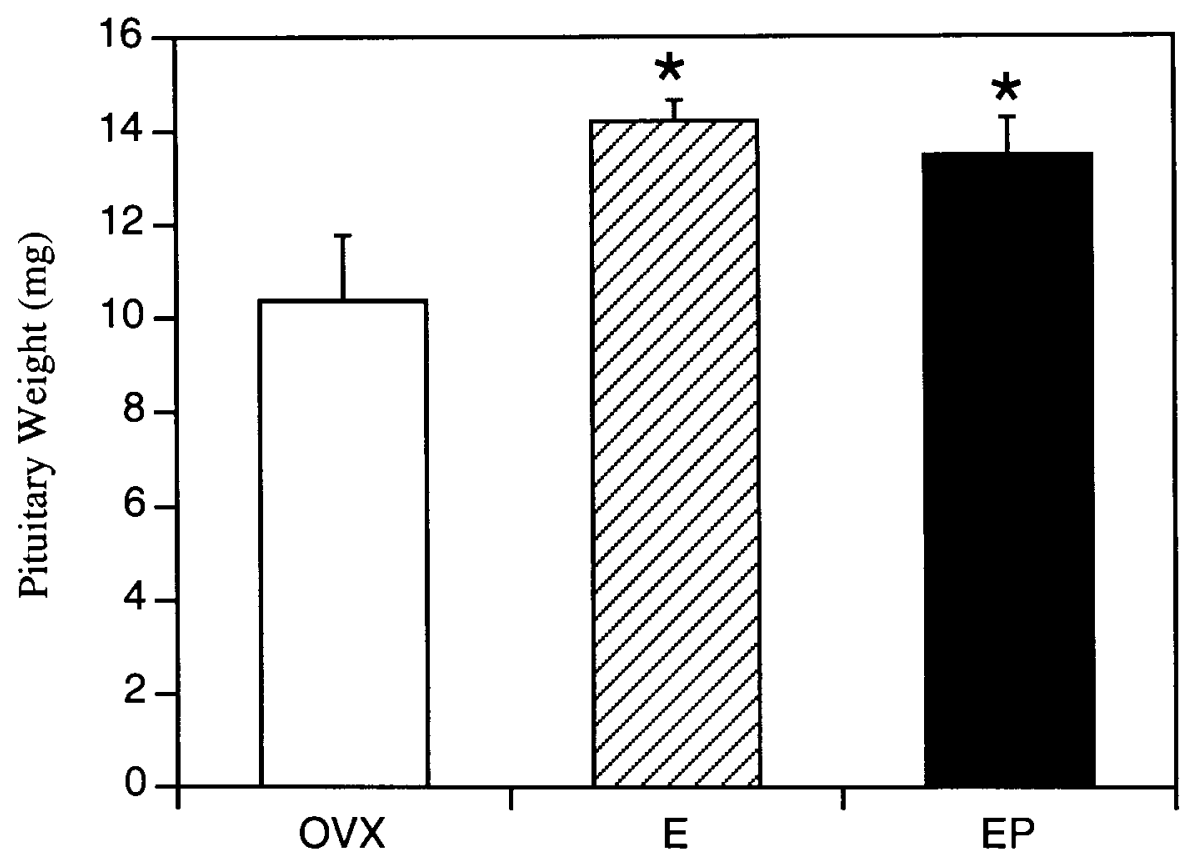

Figure 10. Pituitary wet weight in steroid-treated guinea pigs. Guinea pigs were OVX, estrogen (E)-treated (28 days), and estrogen plus progesterone (EP)-treated (14-day of estrogen and 14-day of estrogen plus progesterone). The average weight of the pituitary glands of estrogen-treated and estrogen plus progesterone-treated groups are significantly higher than that of the OVX group $(*, p<0.05)$. 

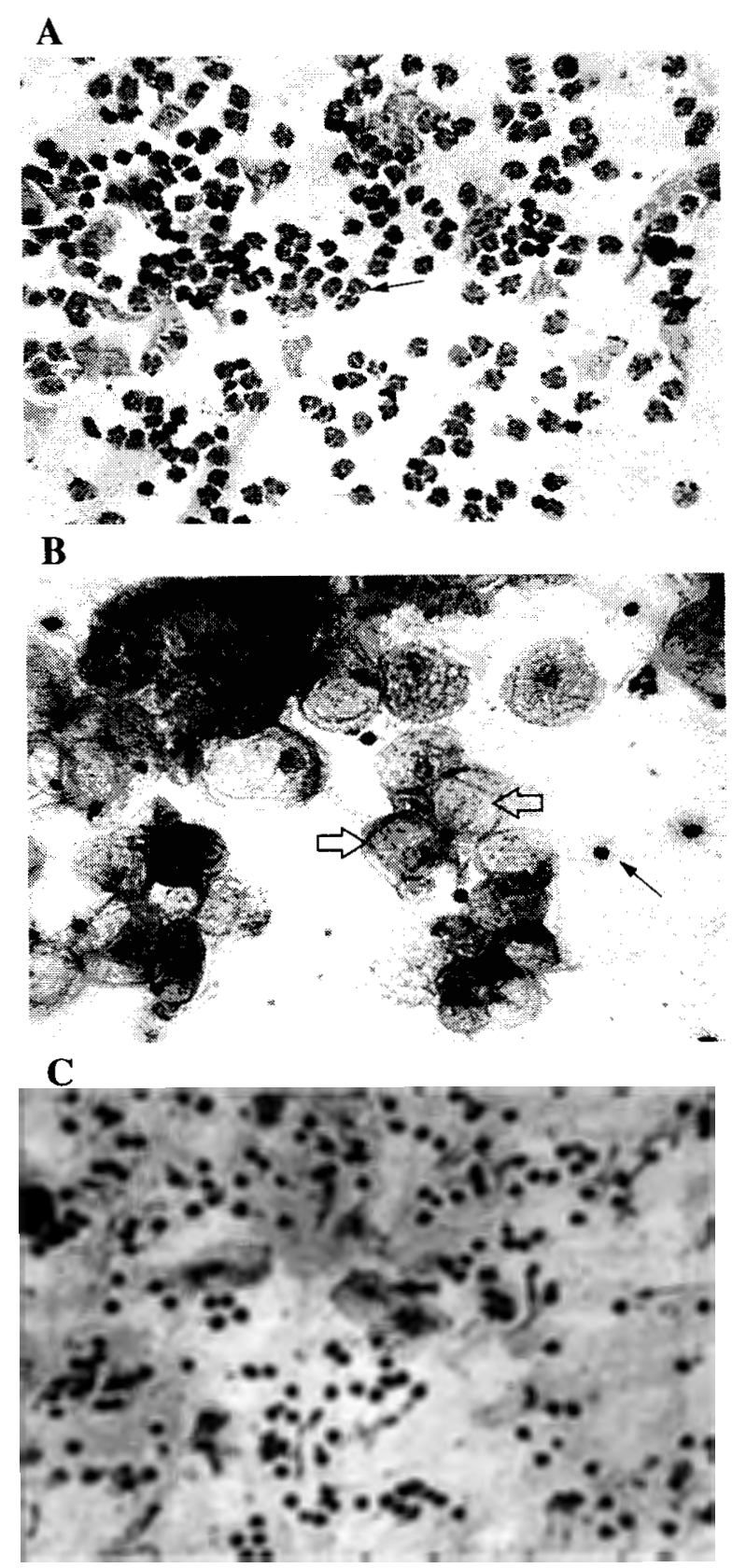

Figure 11. Vaginal smears of steroid-treated guinea pigs. (A) Small leukocytes predominate in the vaginal smears of OVX guinea pigs (thin arrow). B: In estrogentreated guinea pigs, large numbers of cornified squamous epithelial cells are often in clusters (white arrow) C: The infiltration of small leukocytes is the main characteristic of the vaginal smears of estrogen plus progesterone-treated guinea pigs. A few epithelial cells with visible nucleus appear occasionally (solid thick arrow). 
Table 1. Pituitary wet weight ( \pm SEM) after $28 \mathrm{~d}$ of steroid treatment.

\begin{tabular}{cll}
\hline Treatment & $\begin{array}{c}\text { Pituitary Wet Weight } \\
(\mathrm{mg})\end{array}$ & $\begin{array}{l}\text { The Ratio of Pituitary } \\
\text { Weight over Guinea } \\
\text { Pig Body weight } \\
(\mathrm{mg} / \mathrm{g})\end{array}$ \\
\hline OVX $(\mathrm{n}=5)$ & $10.34 \pm 1.42$ & $0.019 \pm 0.0014$ \\
$\mathrm{E}(\mathrm{n}=6)$ & $14.18 \pm 0.46^{* *}$ & $0.027 \pm 0.0014 * * *$ \\
EP $(\mathrm{n}=5)$ & $13.48 \pm 0.76^{* *}$ & $0.025 \pm 0.0012 * *$ \\
\hline $\begin{array}{l}* * \text { significantly different from OVX }(\mathrm{p}<0.05) ; * * * \text { significantly } \\
\text { different from OVX group }(\mathrm{p}<0.01) . \mathrm{E}, \text { estrogen-treated group; EP, estrogen plus } \\
\text { progesterone-treated group. }\end{array}$
\end{tabular}


Table 2. Serum estrogen and progesterone levels ( \pm SEM) after $28 \mathrm{~d}$ of steroid treatment.

\begin{tabular}{lll}
\hline Treatment & Estrogen $(\mathrm{pg} / \mathrm{ml})$ & Progesterone $(\mathrm{ng} / \mathrm{ml})$ \\
\hline OVX & $\begin{array}{l}36.00 \pm 2.65 \\
(\mathrm{n}=3)\end{array}$ & $\begin{array}{l}0.10 \pm 0.10 \\
(\mathrm{n}=5)\end{array}$ \\
E & $\begin{array}{l}141.82 \pm 36.72 * * \\
(\mathrm{n}=11)\end{array}$ & $\begin{array}{l}0.05 \pm 0.03 \\
(\mathrm{n}=6)\end{array}$ \\
EP & $\begin{array}{l}4.13 \pm 0.36^{* * *} \\
(\mathrm{n}=5)\end{array}$ \\
\hline$* *$
\end{tabular}

** significantly different from OVX $(\mathrm{p}<0.01) ; * * *$ significantly different from OVX and E-treated group $(\mathrm{p}<0.001)$. E, estrogen-treated group; $\mathrm{EP}$, estrogen plus progesterone-treated group. 
Table 3. Wet weight (mg \pm SEM) and protein content $(\mu \mathrm{g} \pm \mathrm{SEM})$ of raphe and hypothalamus dissections.

\begin{tabular}{|c|c|c|c|c|c|}
\hline \multicolumn{2}{|l|}{ Dissection } & \multirow{2}{*}{$\begin{array}{r}\begin{array}{r}\text { OVX } \\
(n=5)\end{array} \\
105.32 \\
\pm 5.73\end{array}$} & \multirow{2}{*}{$\begin{array}{c}\begin{array}{c}E \\
(n=6)\end{array} \\
113.93 \\
\pm 8.58\end{array}$} & \multirow{2}{*}{$\begin{array}{c}\begin{array}{c}\text { EP } \\
(n=5)\end{array} \\
102.48 \\
\pm 3.26\end{array}$} & \multirow{2}{*}{$\frac{\text { ANOVA }}{\text { ns }}$} \\
\hline \multirow{4}{*}{ Raphe } & Raphe Wet Weight & & & & \\
\hline & Raphe Protein Content & $\begin{array}{l}3059.00 \\
\pm 260.83\end{array}$ & $\begin{array}{l}3709.17 \\
\pm 362.91\end{array}$ & $\begin{array}{l}3221.00 \\
\pm 272.01\end{array}$ & $\mathrm{~ns}$ \\
\hline & $\begin{array}{l}\text { Ratio of Raphe Total } \\
\text { Protein Content / } \\
\text { Raphe Wet Weight }\end{array}$ & $\begin{array}{l}47.26 \\
\pm 2.36\end{array}$ & $\begin{array}{l}56.12 \\
\pm 4.87\end{array}$ & $\begin{array}{l}48.02 \\
\pm 2.86\end{array}$ & $\mathrm{~ns}$ \\
\hline & $\begin{array}{l}\text { Ratio of Raphe Wet } \\
\text { Weight / Guinea Pig } \\
\text { Body Weight }\end{array}$ & $\begin{array}{l}0.21 \\
\pm 0.02\end{array}$ & $\begin{array}{l}0.20 \\
\pm 0.02\end{array}$ & $\begin{array}{l}0.19 \\
\pm 0.01\end{array}$ & ns \\
\hline \multirow{4}{*}{ Hypothalamus } & $\begin{array}{l}\text { Hypothalamus Wet } \\
\text { Weight }\end{array}$ & $\begin{array}{l}164.88 \\
\pm 20.42\end{array}$ & $\begin{array}{l}166.25 \\
\pm 14.50\end{array}$ & $\begin{array}{l}172.4 \\
\pm 7.89\end{array}$ & ns \\
\hline & $\begin{array}{l}\text { Hypothalamus Protein } \\
\text { Content }\end{array}$ & $\begin{array}{l}2860.40 \\
\pm 334.00\end{array}$ & \multicolumn{2}{|c|}{$\begin{array}{l}3474.17 \pm 3066.80 \\
237.05 \pm 466.10\end{array}$} & ns \\
\hline & $\begin{array}{l}\text { Ratio of } \\
\text { Hypothalamus Protein } \\
\text { Content / } \\
\text { Hypothalamus Wet } \\
\text { Weight }\end{array}$ & $\begin{array}{l}17.71 \\
\pm 1.66\end{array}$ & $\begin{array}{l}21.42 \\
\pm 1.87\end{array}$ & $\begin{array}{l}18.35 \\
\pm 3.43\end{array}$ & ns \\
\hline & $\begin{array}{l}\text { Ratio of } \\
\text { Hypothalamus Wet } \\
\text { Weight / Guinea Pig } \\
\text { Body Weight }\end{array}$ & $\begin{array}{l}0.32 \\
\pm 0.05\end{array}$ & $\begin{array}{l}0.32 \\
\pm 0.04\end{array}$ & $\begin{array}{l}0.32 \\
\pm 0.01\end{array}$ & ns \\
\hline
\end{tabular}

ns, non-significant; E, estrogen-treated group; EP, estrogen plus progesteronetreated group. 


\section{DISCUSSION}

Graur et al. challenged the traditional taxonomy classifying guinea pigs in Rodentia and proposed to consider guinea pigs as a separate mammalian order [101]. This proposal is based on protein sequence analysis and observations on many physiological features of guinea pigs. Indeed, not only the evolution of genes suggests that guinea pigs are different from rats, but also the physiology of guinea pigs is very different from rats. A prolonged luteal phase with elevated progesterone levels is present in humans, primates, and guinea pigs, but not in rats. In rats, prolactin secretion is confounded by a circadian rhythm and estrogen alone can initiate prolactin secretion [87]. Prolactin secretion in primates and guinea pigs, in contrast, is stimulated by estrogen plus progesterone, but not by estrogen alone $[15,16]$. This study showed that estrogen increased TPH enzyme in the raphe in guinea pigs, in correlation with the finding that estrogen increases the TPH mRNA levels in the raphe in monkeys. Moreover, in both guinea pigs and monkeys, addition of progesterone to the estrogen treatment did not modify the effect of estrogen. Thus, the result of this experiment supports the hypothesis that guinea pigs are more like monkeys than they are like rats and that guinea pigs are a better model than rats for the studies on the ovarian steroid regulation of serotonin and prolactin.

Several lines of evidence support the hypothesis that progesterone stimulates prolactin secretion via the serotonin neural systems [22-24]. Many pharmacological studies have shown a stimulatory effect of serotonin on prolactin secretion in rodents [23]. For example, the serotonin precursor, 5-hydroxytryptophan, alone or with fluoxetine (a serotonin reuptake inhibitor) stimulated prolactin secretion [23]. 
Serotonin receptor subtypes, serotonin 1 , serotonin2, and serotonin3 are involved in the regulation of prolactin [102]. 8-OH-DPAT, the serotonin $1 \mathrm{~A}$ receptor agonist, increases serum prolactin [103-105]. In addition, PCPA, a serotonin synthesis inhibitor, or ketanserin, a serotonin 2 receptor antagonist reduces prolactin secretion in pregnant rats [106]. Furthermore, the serotonergic system has been implicated in regulating prolactin secretion in humans [107].

TPH is the rate-limiting enzyme for serotonin synthesis [41]. TPH mRNA is increased by estrogen alone and progesterone has no effect on TPH gene expression in monkeys [95]. However, serotonin levels in the guinea pig raphe were increased by estrogen plus progesterone-treatment but not by estrogen alone [16]. Thus, there is a discrepancy between the effect of steroids on the gene expression of the synthetic enzyme in monkeys and on the levels of the final serotonin product in guinea pigs. I questioned whether the discrepancy came from a species difference between guinea pigs and monkeys, or whether progesterone could act on posttranscriptional processes of TPH gene.

This study showed that, in OVX guinea pigs, estrogen treatment increased TPH enzyme levels in the midbrain raphe and progesterone administration, in addition to estrogen regimen, had no further effect. However, estrogen treatment did not increase hypothalamic serotonin levels whereas progesterone with estrogen increased serotonin levels in the hypothalamus. Thus, progesterone increased serotonin levels without affecting the production of TPH enzyme. Although estrogen stimulated TPH enzyme production, estrogen alone was insufficient to increase serotonin levels. The steroid regulation of TPH protein in guinea pigs is consistent with the steroid regulation of TPH mRNA in monkeys. Thus, the discrepancy described above is not simply due to a species difference. Rather, there continues to 
be a discrepancy between the mass of the synthetic enzyme and the final transmitter product in the same species, i.e., guinea pigs.

The observation that progesterone had no further effect on TPH enzyme ruled out the possibility that progesterone regulates the post-transcriptional processing of the TPH gene. Thus, the ability of progesterone to increase serotonin levels does not occur by stimulation of TPH production. A tissue-specific translation efficiency has been demonstrated in rats [97]. The TPH mRNA level in the raphe is 150 times lower than that in the pineal gland. Yet, TPH $m R N A$ from one raphe yields approximately the same amount of TPH protein as TPH mRNA from one pineal gland does in vitro, suggesting the presence of different mechanisms regulating posttranscriptional events in the pineal and in the raphe. These mechanisms could be the target for progesterone action. However, since ovarian steroids regulate the TPH mRNA in monkeys and TPH protein in guinea pigs in the same manner, it is unlikely that progesterone plays a role in the regulation of the translation efficiency of the TPH gene in the raphe of female guinea pigs. TPH mRNA regulation by estrogen and progesterone in guinea pigs needs to be examined to verify this speculation.

The finding that progesterone increased serotonin without affecting TPH enzyme mass suggested that progesterone might affect the activity of the synthetic enzyme for serotonin. The increase in the specific activity of TPH enzyme may cause an increase in the production of serotonin. Progesterone could modify the specific activity of TPH in a numbers of ways, such as regulating the phosphorylation of the enzyme. Cyclic adenosine 3',5'-monophosphate (cAMP)dependent phosphorylation of the TPH is believed to be of functional significance for the activation TPH enzyme $[108,109]$. Protein kinase A increases the TPH activity $[110,111]$. Also, calmodulin-dependent protein kinase II is involved in the activation 
of TPH enzyme [112,113]. Recent reports indicate that 14-3-3 activator protein family binds with phosphorylated-TPH and activates TPH [114,115]. Thus, progesterone may stimulate the protein phosphorylation and activation systems to increase TPH enzyme activity and the increased TPH activity results in an increase of serotonin. Progesterone reduces the cAMP content in rat lungs [116]. However, studies on reproductive tissues and pineal glands in rats have shown that progesterone stimulates cAMP system $[117,118]$. Furthermore, simultaneous administration of estrogen and progesterone strongly activates cAMP-dependent protein kinases in mammary tumor cells of mice [119]. The question of whether progesterone may affect TPH activity via protein phosphorylation in the cytoplasm remains to be answered.

Also in this experiment, the ratio of dopamine over the major metabolite of dopamine, homovanillic acid, in the hypothalamus was increased significantly by estrogen plus progesterone treatment, but not by estrogen alone. The increased dopamine/homovanillic acid ratio caused by progesterone treatment indicates that progesterone might decrease the activity of MAO in the hypothalamus. Since MAO is the key metabolizing enzyme for both dopamine and serotonin, a decrease in the activity of MAO will lead to an increase of serotonin. Supporting evidence for progesterone to regulate $\mathrm{MAO}$ is from studies on human placental explants and placental cells in culture $[120,121]$. In both cases, progesterone decreases MAO activity. Studies in rats have also shown that estrogen decreases MAO activity in regions in the hypothalamus [122]. Others in this lab recently measured serotonin and 5-HIAA in monkey cerebrospinal fluid. They showed a significant decrease in 5-HIAA in estrogen plus progesterone-treated monkeys, indicating that progesterone is very likely decreasing MAO. Hence, in addition to increasing the activity of TPH, 
decreasing the activity of MAO might be another mechanism by which progesterone can increase serotonin levels in the raphe and hypothalamic terminal field.

Overall, there are multiple points in the functioning serotonergic system which might be regulated by ovarian steroids, such as serotonin synthesis and degradation, serotonin receptors, and serotonin reuptake. SERT is the transporter protein responsible for serotonin reuptake. A decrease of the function of SERT will increase the availability of serotonin. However, a recent finding in monkeys from this laboratory indicates that progesterone does not decrease SERT mRNA levels in the raphe nuclei [123], suggesting it is unlikely that progesterone increases serotonin levels through regulating SERT at the level of gene expression. Again, however, progesterone may be regulating the phosphorylation of SERT.

Serotonin receptors consist of diverse groups of subtypes and these different subtypes can be stimulatory and inhibitory. Information about effects of progesterone on the expression and function of these serotonin receptor subtypes is limited to rats. Serotonin2 receptors are stimulatory, post-synaptic receptors which act through the phosphoinositol pathway $[81,82]$ whereas serotonin $1 \mathrm{~A}$ receptors may be pre- or post-synaptic [83]. As autoreceptors, serotonin 1A receptors inhibit the activity of serotonin neurons. A recent report suggests that the serotonin $1 \mathrm{~A}$ autoreceptor is related to the prevention of the calcium-calmodulin-dependent activation of TPH [124]. In rats, prolonged treatment with estrogen or progesterone induces a down regulation in serotonin 1 receptors, whereas the number of serotonin2 receptor goes up in female cortex $[84,85]$. Thus, progesterone may increase prolactin secretion by increasing expression of serotonin 2 receptors.

GABA neurons in the hypothalamus could also play an important role in transducing the effect of progesterone and regulating prolactin secretion. GABA 
neurons contain progestin receptors [125] and GABA agonists increase prolactin secretion in rodents [22]. GABA is an inhibitory transmitter. GABA neurons have projections on tuberoinfindibular dopamine (TIDA) neurons $[126,127]$. Thus, GABA neurons could transduce the action of progesterone to TIDA neurons, which in turn may affect the secretion of the lactotropes in the pituitary. Moreover, estrogen rapidly attenuates a GABA receptor response in the MBH nuclei [128]. Unfortunately, the question of how progesterone can regulate functions of GABA neurons has not been answered. Antagonist tests on GABA regulation of prolactin secretion have not been done. In the search for the neural pathways which transduce the effect of progesterone on prolactin secretion, the communication between neurons in the hypothalamus and in the raphe needs to be further elaborated. Serotonin neurons originating from the raphe synapse on progestin receptor-containing GABA neurons[129]. PR-containing neurons in the ventrolateral hypothalamus, which are implicated in the regulation of female sexual behavior of guinea pigs, project to the raphe [129]. Agonists for GABA receptors increases serotonin levels in the raphe [130]. Progestin receptor expression in neuroendocrine neurons in the hypothalamus [131] and serotonin neurons in the raphe of monkeys [26] are induced by estrogen and maintained in the presence of progesterone, consistent with the effect of progesterone on prolactin secretion. However, the hierarchy and communication between these neurons in regulating prolactin secretion needs to be clarified. The question of whether serotonin, GABA, and other neural systems are conveying the effect of progesterone in turn or whether they are exerting their effects on prolactin secretion synergistically remains to be answered.

Serotonin has been correlated with depression. The condition of depressed patients became worse following administration of the serotonin synthesis inhibitor 
PCPA [132]. Brain serotonin levels are, to some degree, dependent on plasma tryptophan concentrations [133]. It has been shown that a severe depletion of plasma tryptophan markedly alters the mood and behavior of patients [133]. In patients with major depression, the serotonergic system may be dysfunctional. Prolactin has been used as a marker for serotonin function in humans. Hence, prolactin release in depressed patients is blunted during intravenous injection of tryptophan, compared to the healthy controls [134]. Blunted prolactin responses to fenfluramine, a serotonin releasing agent, has also been found in patients with mood disorders [135]. In women with premenstrual syndromes, altered serotonergic activity has been documented [136]. Furthermore, during chronic stress, anatomical adaptation has been found in the serotonergic systems [137]. Meta-chlorophenylpiperazine, a serotonin agonist can produce elevated mood in healthy volunteers [138]. Moreover, the major antidepressants available today, including Prozac, are agents which can increase 5 -HT levels in the synapse [139].

The observation that estrogen increased the TPH enzyme levels significantly and the addition of progesterone had no further effect might provide a biological basis for depression related to reproductive function in women. The withdrawal of ovarian steroids has been correlated with mood disorders, such as premenstrual syndrome, post-hysterectomy depression, postpartum depression, and postmenopausal depression [140,141]. For example, irritablility, depression, and emotional lability affect two-thirds of women in the first week post partum [142]. Estrogen and progesterone fall abruptly on the first day of partum [143]. Hence, there appears a correlation between the abrupt decline of steroid levels and depression. Clinical studies show a moderate increase in estrogen levels can lead to a pleasant feeling of well-being [144]. High dose of oral estrogen supplement 
effectively alleviates depression in patients who failed to respond to conventional antidepressant treatment [144]. High progesterone levels during the menstrual cycle are associated with relieving premenstrual syndrome and stabilizing mood as well [145,146]. 


\section{CONCULUSIONS}

The information available today indicates that estrogen plus progesterone increases prolactin and serotonin in guinea pigs. This experiment demonstrated that estrogen approximately doubled the TPH enzyme level in the raphe of ovariectomized guinea pigs and supplemental progesterone had no additive effect. Estrogen plus progesterone did increase serotonin levels in the hypothalamic terminal fields of serotonin neurons, but estrogen alone did not show this effect. Thus, there continues to be a discrepancy between the mass of the synthetic enzyme and the level of the final serotonin product. A logical hypothesis is that progesterone might affect the activity of TPH enzyme. The increase in the activity of TPH enzyme could lead to the increase in serotonin level.

On the other hand, progesterone could decrease the degradation enzyme for serotonin, MAO, to increase serotonin. The result from this experiment showed that progesterone plus estrogen, but not estrogen alone, increased dopamine/homovanillic acid ratio in the hypothalamus, suggesting that progesterone may regulate the activity of MAO. The effects of progesterone on the gene expression, enzyme protein production, and enzyme activity of MAO interesting areas for further study.

In summary, these results indicate that progesterone does not act at the level of post-transcriptional processing of the TPH gene to increase serotonin or prolactin levels. However, they do suggest an important mechanism by which ovarian steroids can affect mood in women. 


\section{REFERENCES}

1 Neill JD, Nagy GM: Prolactin secretion and its control; in Knobil E, Neill JD (eds): The Physiology of Reproduction. New York, Raven Press, 1994, vol 1, pp 1833-1860.

2 Nicoll CS: Endocrinology: physiological actions of prolactin; in Knobil E, Sawyer WH (eds): Handbook of Physiology. Washington DC, American Physiological Society, 1974, vol 4, sect 7, pp 253-292.

3 De Vlaming VL: Actions of prolactin among vertebrates; in Barrington EJW (ed): Hormones and Evolution. New York, Academic Press, 1979, pp 561642.

4 Leong DA, Frawley SL, Neill JD: Neuroendocrine control of prolactin secretion. Ann Rev Physiol 1983;45:109-127.

5 Nicoll,CS, Bern HA: On the actions of prolactin among the vertebrates: is there a common denominator; in Wolstenholme GEW, Knight J (eds): Lactogenic Hormones. Churchill Livingstone, London, 1972, pp 299-324.

6 Smith PE: Effect of hypophysectomy on the involution of the thymus in the rat. Anat Rec 1930;47:119-129.

7 Chikanza IC, Panayi, GS: Hyothalamic-pituitary mediated modulation of immune function: prolactin as a neuroimmune peptide. Br J Rheumat 1991; 30:203-207.

8 O'Keane V, Dinan TG: Prolactin and cortisol responses to $d$-Fenfluramine in major depression: evidence for diminished responsivity of central serotonergic function. Am J Psychiatry 1991;148:1009-1015. 
9 Anderson IM, Ware CJ, Da Roza Davis JM, Cowen PJ: Decreased 5-HTmediated prolactin release in major depression. Br J Psychiatry 1992;160:372-378.

10 Friesen H, Forsbach G: Prolactin secretion during pregnancy and lactation; in Jaffe RB (ed): Prolactin. New York, Elsevier North Holland Inc., 1981, pp 167-180.

11 Dijursing $\mathrm{H}$, Hagen C, Moller J, Christiansen C: Short- and long-term fluctuations in plasma prolactin concentration in normal subjects. Acta Endocrinol (Copenh) 1981;98:1-6.

12 Buvat J, Buvat-Herbaut $\mathrm{M}$ : Changes in the gonadotrophins, in the prolactin and in the sexual steroid levels throughout the normal menstrual cycle (author's transl.) [French]. J Gynecol Obstet Biol Repr (Paris) 1981;10:99108.

13 Vekemans M, Delvoye P, L'Hermite M, Robyn C: Serum prolactin levels during the menstrual cycle. J Clin Endocrinol Metab 1977;44:989.

14 Butler WR, Krey LC, Lu KH, Peckam WD, Knobil E: surgical disconnection of the medial basal hypothalamus and pituitary function in the rhesus monkey. IV. Prolactin secretion. Endocrinology 1975;96:1099-1105.

15 Williams RF, Gianfortoni JG, Hodgen GD: Hyperprolactinemia induced by an estrogen-progesterone synergy: quantitative and temporal effects of estrogen priming in monkeys. J Clin Endocrinol Metab 1985;60:126-132.

16 Bethea CL, Hess DL, Widmann AA, Henningfeld JM: Effects of progesterone on prolactin, hypothalamic $\beta$-endorphin, hypothalamic substance $P$, and midbrain serotonin in guinea pigs. Neuroendocrinology 1995;61:695-703. 
17 Milmore JD: Influence of ovarian hormones on prolactin release in the rhesus monkey. Biol Reprod 1978;19:593-596.

18 Frawley LS, Neill JD: Effect of estrogen on serum prolactin levels in rhesus monkeys after hypophyseal stalk-transection. Biol Reprod 1980;22:10891093.

19 Sprangers SA, West NB, Brenner RM, Bethea CL: Regulation and localization of estrogen and progestin receptors in the pituitary of steroidtreated monkeys. Endocrinology 1990;126:1133-1142.

20 Fox SR, Harlan RE, Shivers BD, Pfaff DW: Chemical characterization of neuroendocrine targets for progesterone in the female rat brain and pituitary. Neuroendocrinology 1990;51:276-283.

21 Gasc JM, Baulieu EE: Regulation by estradiol of the progesterone receptor in the hypothalamus and pituitary: an immunohistochemical study in the chicken. Endocrinology 1988;122:1357-1365.

22 Kordon C, Drouva SV, Martinez de L'Escaler G, Weiner RI: Role of classic and peptide neruomediators in the neruoendocrine regulation of luteinizing hormone and prolactin; in Knobil E, Neill JD (eds): The Physiology of Reproduction. New York, Raven Press, vol 1, 1994, pp 1621-1681.

23 van de Kar LD, Urban JH, Richardson KD, Bethea CL: Pharmacological studies on the serotonergic and non serotonin-mediated stimulation of prolactin and corticosterone secretion by fenfluramine. Neuroendocrinology 1985;37:200-205.

24 van de Kar LD, Lorens SA,, Urban JH, Bethea CL: Effect of selective serotonin (5-HT) agonists and 5- $\mathrm{HT}_{2}$ antagonist on prolactin secretion. Neuropharmacology 1989;28:299-303. 
25 Bethea CL: Colocalization of progestin receptors with serotonin in raphe neurons of macaque. Neuroendocrinolgy 1993;57:1-6.

26 Bethea CL: Regulation of progestin receptors in raphe neurons of steroidtreated monkeys. Neuroendorinology 1994;60:50-61.

27 Parent A, Descarries L, Beaudet A: Organization of ascending serotonin systems in the adult rat brain. A radioautographic study after intraventricular administration of [3H]S-hydroxytryptamine. Neuroscience 1981;6:15-138.

28 Steinbusch HWM: Distribution of serotonin-immunoreactivity in the central nervous system of the rat-cell bodies and terminals. Neuroscience $1981 ; 6: 557-618$.

29 Steinbusch HWM: Serotonin-immunoreactive neurons and their projections in the CNS; in Bjorklund A, Hokfelt T, Kuhar MJ (eds): Handbook of Chemical Neuroanatomy: Classical Transmitters and Transmitter Receptors in the CNS. Amsterdam, Elsevier, vol 3 (11), 1984, pp 68-125.

30 Steinbusch HWM, Nieuwenhuys R: The raphe nuclei of the rat brainstem: A cytoarchitectonic and immunohistochemical study; in Emson PC (ed): Chemical Neuroanatomy. New York, Raven Press, 1983, pp 131-207.

31 Tork, I: Raphe nuclei and serotonin containing systems; in Paxinos G (ed): The Rat Nervous System. Sydney, academic Press, vol 2, 1985, pp 43-78.

32 Azmitia EC, Gannon PH: The primate serotonergic system: A review of human and animal studies and a report on Macaca fascicularis. Adv Neurol 1986;43:407-468.

33 Takahashi, HS, Nakashima E, Ohama S, Takeda S, Ikuta F: Distribution of serotonin-containing cell bodies in the brainstem of the human fetus 
deternined with immunohistochemistry using antiserotonin serum. Brain Dev 1986;8:355-365.

34 Baker KG, Halliday GM, Halasz P, Hornung JP, Geffen LB, Cotton RG, Tork I: Cytoarchitecture of serotonin-synthesizing neurons in the pontine tegmentum of the human brain. Synapse 1991;7:301-320.

35 Halliday GM, Li YW, Joh TH, Cotton RGH, Howe PRC, Geffen LB, Blessing WW: Distribution of monoamine-synthesizing neurons in the human medulla oblongata. J Comp Neurol 1988;273:301-317.

36 Jacobs BL, Gannon PJ, Azmitia EC: Atlas of serotonergic cell bodies in the cat brainstem: An immunohistochemical analysis. Brain Res Bull 1984;13:13.

37 Tillet Y: Immunocytochemical localization of serotonin-containing neurons in the mylencephalon, brainstem and diencephalon of the sheep. Neuroscience 1987;23:501-527.

38 Tork I: Anatomy of the serotonergic system; in Whitaker-Azmitia PM, Peroutka SJ (eds): The Neuropharmacology of Serotonin. New York, Ann NY Acad Sci, vol 600, 1990. pp 9-35.

39 Molliver ME: Serotonergic neuronal systems: What their anatomic organization tells us about function. J Clin Psychopharmacol 1987;7 (6 suppl.):3s-23s.

40 Jacobs BL, Azmitia, EC: Structure and function of the brain serotonin system. Physiol Rev 1992;72:165-229.

41 Frazer A, Hensler JG: Serotonin; in Siegel GJ, Agranoff BW, Albers RW, Molinoff PB (eds): Basic Neurochemistry. New York, Raven Press, 1994. pp 283-308. 
42 Lidov HGW, Molliver ME: Immunohistochemical study of the development of serotonergic neurons in the rat CNS. Brain Res 1982;78:45-56.

43 Aitken AR, Tork I: Early development of serotonin-containing neurons and pathways as seen in wholemout preparations of the fetal rat brain. J Comp Neurol 1988;274:32-47.

44 Olson L, Seiger A: Early prenatal ontogeny of central monoamine neurons in the rat: Fluorescence histochemical observations. Z Anat Entwickl Gesch 1972;137:301-316.

45 Steinbusch HWM: Distribution of serotonin-immunoreactivity in the central nervous system of the rat. Neuroscience 1981;4:557-618.

46 Mulligan KA, Tork I: Serotoninergic innervation of the cat cerebral cortex. J Comp Neurol 1988;270:86-110.

47 Fallon JH, Loughlin SE: Monoamine enervation of cerebral cortex and a theory of the role of monoamines in cerebral cortex and basal ganglia; in Peters A, Jones EG (eds): Cerebral Cortex. New York, Plenum Press, 1987, pp 41-127.

48 Molliver ME, Grzanna R, Lidov HGW, Morrison JH, Olschowska JA: Monoamine systems in the cerebral cortex; in Chan-Palay V, Palay SL (eds): Cytochemical Methods in Neuroanatomy. New York, Alan Liss, 1982, pp 255-257.

49 Cropper EC, Eisenman JS, Azmitia EC: An immunocytochemical study of the serotonergic innervation of the thalamus of the rat. J Comp Neurol 1984; 224:38-50. 
50 Costa E, Aprison MH: Studies on the 5-hydroxytryptamine (serotonin) content in human brain. J Nerv Ment Dis 1958;126:289-293.

51 Dahlstrom A, Fuxe K: Evidence for the existence of monoamine-containing neurons in the central nervous system. I. Demonstration of monoamines in cell bodies of brain stem neurons. Acta Physiol Scand Suppl 1964;232:1-55.

52 Morrison JH, Foote SL: Noradrenergic and serotonergic innervation of cortical, thalamic, and tectal visual structures in old and new world monkeys. J Comp Neurol 1986;243:117-138.

53 Azmitia EC, Segal M: An autoradiographic analysis of the differential ascending projections of the dorsal and median raphe nuclei in the rat. $\mathrm{J}$ comp Neurol 1970;179:641-668.

54 Bosler C, Joh TH, Beaudet A: Ultrastructural relationships between serotonin and dopamine neurons in the rat arcuate nucleus and medial zona incerta: A combined radioautographic and immunocytochemical study. Neurosci Lett 1984;48:279-285.

55 Kiss J, Halasz B: Synaptic connections between serotonergic axon terminals and tyrosine hydroxylase-immunoreactive neurons in the arcuate nucleus of the rat hypothalamus. A combination of electron microscopic autoradiography and immunocytochemisty. Brain Res 1986;364:284-294.

56 Delgado PL, Charney DS, Price LH, Aghajanian GK, Landis H, Heninger GR: Serotonin function and the mechanism of antidepressant action. Arch Gen Psychiatry 1990;47:411-418.

57 Celada P, Artigas F: Plasma 5-hydroxyindoleacetic acid as an indicator of monoamine oxidase- $\mathrm{A}$ inhibition in rat brain and peripheral tissues. J Neurochemistry 1993;61:2191-2198.. 
58 Fornal CA, Metzler CW, Jacobs BL: Role of somatodendritic 5HT1A autoreceptors in the regulation of brain 5HT neuronal activity in behaving cats. Progaram of the Third IUPHAR Satellite Meeting on Serotonin, Chicago, IL, Symposium 1994;20:48.

59 Wauquier A, Dugovic C: Serotonin and sleep-wakefulness; in Whitaker-Azmitia PM, Peroutka SJ (eds): The Neuropharmacology of Serotonin. New York, Ann NY Acad Sci, vol 600, 1990, pp 460-459.

60 Prosser RA, Miller JD, Heller Ca: A serotonin agonist phase-shifts the circadian clock in the suprachiasmatic nuclei in vitro. Brain Res 1990;534:336-369

61 Morin LP, Michels KM, Smale L, Moore RY: Serotonin regulation of circadian rhythmicity; in Whitaker-Azmitia PM, Peroutka SJ (eds): The Neuropharmacology of Serotonin. New York, Ann NY Acad Sci, vol 600, 1990, pp 418-426.

62 Curzon G: Serotonin and Appetite; in Whitaker-Azmitia PM, Peroutka SJ (eds): The Neuropharmacology of Serotonin. New York, Ann NY Acad Sci, vol 600, 1990, pp 521-531.

63 Meltzer HY: Role of serotonin in depression; in Whitaker-Azmitia PM, Peroutka SJ (eds): The Neuropharmacology of Serotonin. New York, Ann NY Acad Sci, vol 600, 1990, pp 486-500.

64 Meyer DC: Hypothalamic and raphe serotonergic systems in ovulation control. Endocrinology 1978;103:1067-1074.

65 Mendelson SD, Watson NV: Serotonin receptor subtypes and sexual behavior; in Whitaker-Azmitia PM, Peroutka SJ (eds): The Neuropharmacology of Serotonin. New York, Ann NY Acad Sci, vol 600, 1990, pp 435-446. 
66 Boranic M, Pericic D, Poljak-Blazi M, Sverko V, Marotti T: Suppression of immune response in rats by stress and drugs interfering with metabolism of serotonin. Ann NY Acad Sci 1987;496:485-491.

67 Kitay JI: Pituitary-adrenal function in the rat after gonadoectomy and gonadal hormone replacement. Endocrinology 1963;73:253-260.

68 Azmitia EC Jr, McEwen BS: Adrenalcortical influence on rat brain tryptophan hydroxylase activity. Brain Res 1974;78:291-302.

69 Sze PY, Neckers L, Towle AC: Glucocorticoids as a regulatory factor for brain tryptophan hydroxylase. J Neurochem 1976;26:169-173.

70 Aldegunde M, Arnaez E, Miguez I, Fernandez P: Variations in monoamine contents in discrete brain regions and their concomitance with plasma corticosteroids during the day. Int J Neurosci 1984;24:233-238.

71 Jhanwar-Uniyal M, Renner K, Bailo M, Luine VN, Leibowitz SF: Serotonin and 5-hydroxyindoleacetic acid levels in discrete hypothalamic areas of the rat brain: relation to circulating corticosterone. Neurosci Lett 1987;79:145-150.

72 De Kloet ER, Sybesma H, Reul HM: Selective control by corticosterone of serotonin 1 receptor capacity in raphe-hippocampal system.

Neuroendocrinology 1986;42:513-521.

73 Endersby CA, Wilson CA: The effect of ovarian steroids on the accumulation of ${ }^{3} \mathrm{H}$-labeled monoamines by hypothalamic tissue in vitro. Brain Res 1974;73:321-331.

74 Wirz-Justice A, Hackman E, Lichtsteiner M: The effect of oestradiol dipropionate and progesterone on monoamine uptake in rat brain. $\mathrm{J}$ Neurochem 1974;22:187-189. 
75 Kendall DA, Tonge SR, Leonard BE: Effects of testosterone and ethinyloestradiol on the synthesis and uptake of noradrenaline and 5hydroxytryptamine in rat hindbrain: evidence for a presynaptic regulation of monoamine synthesis? Br J Pharmacol 1977;60:310-311.

76 Cone RI, Davis GA, Goy RW: Effects of ovarian steroids on serotonin metabolism within grossly dissected and microdissected brain regions of the ovariectomized rat. Brain Res Bull 1981;7:639-644.

77 DiPaolo TM, Daigle M, Picard V, Barden N: Effect of acute and chronic 17-beta-estradiol treatment on serotonin and 5-hydroxyindole acetic acid content of discrete brain nuclei of ovariectomized rat. Exp Brain Res 1983;51:73-76.

78 Walker RF, Wilson CA: Changes in hypothalamic serotonin associated with amplification of LH surges by progesterone in rats.. Neuroendocrinology $1983 ; 37: 200-205$.

79 King TS, Steger RW,, Morgan WW: Effect of ovarian steroids to stimulate region-specific hypothalamic 5-hydroxytryptamine synthesis in ovariectomized rats. Neuroendocrinology 1986;42:344-350.

80 Jahn GA, Deis RP: A possible dual regulation of prolactin release by the serotoninergic system in rats at pro-oestrus and during late pregnancy. $J$ Endocrinol 1987;112:367-374.

81 Molinoff PB, Ferry RC: Properties and regulation of 5HT2 receptors in P11 cells. Program of the Third IUPHAR Satellite Meeting on Serotonin, Chicago, IL, Symposium 1994;17:37.

82 Sanders-Bush E: Does negative intrinsic activity of 5HT2A/C receptor antagonists explain their unusual ability to elicit 5HT2C receptor down 
regulation? Program of the Third IUPHAR Satellite Meeting on Serotonin, Chicago, IL, Symposium 1994;17:38.

83 Sipes TA, Geyer MA: Pre-and Postsynaptic sites of action of 8-OH-DPAT disruption of prepulse inhibition in the rat. Program of the Third IUPHAR Satellite Meeting on Serotonin, Chicago, IL, Abstract 1994;18: 63.

84 Biegon A, McEwen BS: Modulation by estradiol of serotonin receptors in brain. J Neuroscience 1982;2:199-205.

85 Biegon A, Reches A, Snyder L, McEwen BS: Serotonergic and noradrenergic receptors in the rat brain: Modulation by chronic exposure to ovarian hormones. Life Sci 1983;32:2015-2021.

86 Payette RF, Gershon MD, Nunez EA: Serotonergic elements of the mammalian pituitary. Endocrinology 1985;116:1933-1942.

87 Freeman ME: The neuroendocrine control of the ovarian cycle of the rat; in Knobil E, Neill JD (eds): The Physiology of Reproduction. New York, Raven Press, 1994, vol 2, pp 613-658.

88 Young WC, Dempsey EW, Myers HI: Cyclic reproductive behavior in the female guinea pig. J Comp Physiol Psychol 1935;19:313-335.

89 Blandau RJ, Young WC: The effects of defertilization on the development of the guinea pig ovum. Amer J Anat 1939;64:303-330.

90 Myers HI, Young WC, Dempsey EW: Graafian follicle development throughout the reproductive cycle in the guinea pig, with special reference to changes during oestrus (sexual receptivity). Anat Rec 1936;65:381-402. 
91 Challis JR, Heap RB, Illingworth DV: Concentrations of oestrogen and progesterone in the plasma of non-pregnant, pregnant and lactating guinea pigs. J Endocrinol 1971;51:333-345.

92 Croix D, Franchimont P: Changes in the serum levels of the gonadotropins, progesterone and estradiol during the estrous cycle of the guinea pig. Neuroendocrinology 1975;19:1-11.

93 Pfaff D, Keiner M: Atlas of estradiol-concentrating cells in the central nervous system of the female rat. J Comp Neurol 1973;151:121-158.

94 Gerlach JL, McEwen BS: Rat brain binds adrenal steroid hormone: Radioautography of hippocampus with corticosterone. Science 1972; $175: 1133-1136$.

95 Pecins-Thompson M, Brown NA, Kohama SG, Bethea CL: Ovarian steroid regulation of tryptophan hydroxylase mRNA expression in thesus macaques. J Neurosci 1996;16:7021-7029.

96 Bradford MM: A rapid and senstive method for the quantitation of microgram quantities of protein utilizing the princinple of protein-dye binding. Anal Biochem 1976;72:248-254.

97 Dumas S, Darmon MC, Delort J, Mallet J: Differential control of tryptophan hydroxylase expression in raphe and in pineal gland: Evidence for a role of translation efficiency. J Neurosci Res 1989;24:537-547.

98 Brandon DD, Bethea CL, Strawn EY, Novy MJ, Burry KA, Harrington MS, Erickson TE, Warner C, Keenan EJ, Clinton GM: Progesterone receptor messenger ribonucleic acid and protein are overexpressed in human uterine leiomyomas. Am J Obstet Gynecol 1993;169:78-85. 
99 Resko JA, Norman RL, Niswender GD, Spies HG: The relationship between progestins and gonadotropins during the late luteal phase of the menstrual cycle in rhesus monkeys. Endocrinology 1974;94:425-430.

100 Resko JA, Ploem JG, Stadelman H: Estrogens in fetal and maternal plasma of the rhesus monkeys. Endocrinology 1975;97:425-430.

101 Graur D, Hide WA, Li W-H: Is the guinea pig a rodent? Nature 1991;10:171-284.

102 Jorgensen H, Knigge U, Warberg J: Involvement of 5-HT1, 5-HT2, and 5HT3 receptors in the mediation of the prolactin response to serotonin and 5hydroxytryptophan. Neuroendocrinology 1992;55:336-343.

103 Willoughby JO, Menadue MF, Liebelt HJ: Activation of 5-HT1 serotonin receptors in the medial basal hypothalamus stimulates prolactin secretion in the unanaesthetized rat. Neuroendocrinology 1988;47:83-87.

104 Kellar KJ, Hulihan-Giblin BA, Mulroney SE, Lumpkin MD: Stimulation of serotonin 1A receptors increases release of prolactin in the rat. Neuropharmacology 1992;31:643-647.

105 Pan J, Yang IC: Central administration of 8-OH-DPAT and MCPP stimulates prolactin secretion in ovariectomized, estrogen-treated rats: lack of an effect on tuberoinfundibular dopaminergic neuron activity. Life Sciences 1996;58:1189-1194.

106 Mistry AM, Voogt JL: Serotonin synthesis inhibtion or receptor antagonism reduces pregnancy-induced nocturnal prolactin secretion. Life Sciences 1990;47:693-701. 
107 Urban RJ, Veldhuis JD: A selective serotonin reuptake inhibitor, fluoxetin hydrochloride, modulates the pulsatile release of prolactin in postmenopausal women. Am Obstet Gynecol 1991;164:147-152.

108 Lysz TW, Sze PY: Activation of brain trypotophan hydroxylase by a phophorylation system. J Neurosci Res 1978;3:411-418.

109 Kan JP, Buda M, Pujol JF: Calcium dependence of rat brain tryptophan hydroxylase. J Mol Bio 1991;217:125-132.

110 Johansen PA, Jennings I, Cotton RG, Kuhn DM: Tryptophan hydroxylase is phosphorylated by prtein kinase A. J Neurochem 1995;65:882-888.

111 Johansen PA, Jennings I, Cotton RG, Kuhn DM: Phosphorylation and activation of tryptophan hydroxylase by exogenous protein kinase A. J Neurochem 1996;66:817-823.

112 Makita Y, Okuno S, Fujisawa $\mathrm{H}$ : Involvement of acivator protein in the activation of tryptophan hydosylase by cAMP-dependent protein kinase. FEBS letters 1990;268:185-188.

113 Ehret M, Cash CD, Hamon M, Maitre M: Formal demonstration of the phosphorylation of rat brain tryptophan hydroxylase by $\mathrm{Ca} 2+/$ calmodulindependent protein kinase. J Neurochem 1989;52:1886-1891.

114 Isobe $\mathrm{T}$, Ichimura $\mathrm{T}$, Sunaya $\mathrm{T}$, Okuyama T, Takahashi N, Kuwano R, Takahashi Y: Distinct forms of the protein kinase-dependent activator of tyrosine and tryptophan hydroxylases. J Mol Bio 1991;217:125-132.

115 Ichimura T, Uchiyama J, Kunihiro O, Ito M, Horigome T, Omata S, Shinkai F, Kaji H, Isobe T: Identification of the site of interaction of the 143-3 protein with phosphorylated tryptophan hydroxylase. J Bio Chem 1995;270:28515-28518. 
116 Nabishah BM, Khalid BA, Morat PB, Alias AK, Zainuddin M: Effects of steroid hormones on cyclic adenosine 3',5'-monophosphate levels in the rat lung. J Endocrinology 1992;134:73-76.

117 Rosenfeld MG, O'Malley BW: Steroid hormones: effects on adenyl cyclase activity and adenosine 3',5'-monophosphate in target tissues. Science 1970;168:253-255.

118 Weiss B, Crayton J: Gonadal hormones as regulators of pineal adenyl cyclase activtiy. Endocrinology 1970;87:527-533.

119 Morozova TM, Mitina RL, Ozhogina ZB, Sidorkina OM: Activation of protein kinase $\mathrm{C}$ and cAMP-dependent protein kinase in hormone-dependent mammary gland tumors during stimulation of their growth with progesterone and estrone. Biokhimiia 1986;51:1624-1629.

120 Kono H, Lin YC, Yamaguchi M, Zuspan FP, Furuhashi N, Takayam K, Yajima A: Effects of progesterone and gossypol on monoamine oxidase activity in human term placental explant. Tohoku J Exp Med 1991;163:3945.

121 Kono H, Lin YC, Zuspan FP, Lee AC, Yajima A: Effect of ethanol and progesterone on monoamine oxidase activity in cultured cells of human term placenta. Am J Obstet Gynecol 1993;168:136-140.

122 Luine VN, Rhodes JC: Gonadal hormone regulation of MAO and other enzymes in hypothalamic areas; Neuroendocrinology 1983;36:235-241.

123 Pecins-Thompson M, Brown NA, Bethea CL: Regulation of serotonin reuptake transporter (SERT) mRNA expression by estrogen and progesterone in rhesus macaques. Soci Neurosci Abstr 1996;571:5. 
124 Sawada M, NagatsuT: Stimulation of the serotonin autoreceptor prevents the calcium-calmodulin-dependent increase of serotonin biosynthesis in rat raphe slices. J Neurochem 1986;46:963-967.

125 Leranth C, MacLusky NJ, Brown TJ, Chen EC, Redmond DE Jr, Naftolin F: Transmitter content and afferent connections of estrogen-sensitive progestin receptor-containing neurons in the primate hypothalamus. Neuroendocrinology 1992;55:667-682.

126 Leranth C, Sakamoto H, Maclusky NJ, Shanabrough M, Naftolin F: Estrogen responsive cells in the arcuate nucleus of the rat contain glutamic acid decarboxylase (GAD): an electron microscopic immunocytochemical study. Brain Res 1985;331:376-381.

127 Leranth C, Sakamoto H, MacLusky NJ, Shanabrough M, Naftolin F: Intrinsic tyrosine hydroxylase (TH) immunoreactive axons synapse with $\mathrm{TH}$ immunopositive neurons in the rat arcuate nucleus. Brain Res 1985;331:371375 .

128 Lagrange AH, Wagner EJ, Ronnekleiv OK, MJ Kelly: Estrogen rapidly attenuates a $\mathrm{GABAB}$ response in hypothalamic neurons. Neuroendocrinology 1996;64:114-123.

129 Brown TJ, MacLusky NJ, Leranth C, Shanabrough M, Naftolin F: Progestin receptot-containing cells in guinea pig hypothalamus: afferent connections, morphological characteristics, and neurotransmitter content. Mol Cell Neurosci 1990;1:58-77.

130 Auerbach SB, Ma Z, Tao R: Differential inhibitory influence of GABAA and GABAB receptors on serotonin in the raphe and $N$. accumbens of rats. Soc Neurosci Abstr 1995;21:324. 
131 Kohama SG, Freesh F, Bethea CL: Immunocytochemical colocalization of hypothalamic progestin receptors and tyrosine hydroxylase in steroid-treated monkeys. Endocrinology 1992;131:509-517.

132 Shopsin B, Friedman E, Gershon S: Parachlorophenylalanine reversal of tranylcypromine effects in depressed patients. Arch Gen Psychiatry 1976;33:811-819.

133 Delgado PL, Price L, Charney DS, Aghajanian GK, Landis H, Heninger GR: Tryptophan depletion alters mood in depression. Ann Meet Am Psych Assoc 1988;141:189.

134 Heninger GR, Charney DS, Price LH, Delgado P, Woods S, Goodman W: Effects of serotnergic agonists on neuroendocrine responses of rhesus monkeys and patients with depression and anxiety disorders, in Dahl SG, Gram LF (eds): Clinical Pharmacology in Psychiatry, 1989, pp94-104.

135 O'Keane V, Moloney E, O'Neill H, O'Connor A, Smith C, Dinan TG: Blunted prolactin responses to $\mathrm{d}$-fenfluramine in sociopathy evidence for subsensitvity of central serotonergic function. Brit J Psych 1992;160:643646.

136 Halbreich U, Tworek H: Altered sertotonergic activity in women with dysphoric premenstrual syndromes. Intl J Psych Med 1993; 23:1-27.

137 McEwen BS, Mendelson S: Effects of stress on the neurochemistry and morphology of the brain: counterregulation versus damage. in Goldberger L, Breznitz S (eds): Handbook of Stress: Theoretical and Clinical Aspects. New York, Free Press, 1993. pp101-126.

138 Mueller EA, Murphy DL, Sunderland T: Neuroendocrine effects of Mchlorophenylpiperazine, a serotonin agonist, in humans. J Clin Endocrinoal Metab 1985;61:1179-1184. 
139 Meltzer HY, Lowy MT: The serotonin hypothesis of depression. in Meltzer HY (ed): Psychopharmacology: The Third Generation of Progress 1987; New York, Raven Press. pp513-526.

140 Gitlin MJ, Pasnau RO: Psychiatric syndromes linked to reproductive function in women: a review of current knowledge. Am J Psychiatry 1989;146:1413-1422.

141 Harris B, Johns S, Fung H, Thomas R, Walker R, Read G, Riad-Fahmy D: The hormonal enviroment of post-natal depression. Bri J Psychia 1989;154:660-667.

142 Victoroff VM: Dynamics and management of parapartum neuropathic reactions. Dis Nerv Syst 1952; XIII:291-298.

143 Nott PM, Franklin M, Armitage C, Gelder MG: Hormonal changes and mood in the puerperium. Br J Psychiat 1976;128:379-383.

144 Vogel W, Klaiber EL, Broverman DM: Roles of the gonadal steroid hormones in psychiatric depression in men and women. Prog NeuroPsychopharmacol 1978;2:487-503.

145 Glick ID, Bennett SE: Psychiatric complications of progesterone and oral contraceptives. J clin Pscychopharmacol 1981;1:350-367.

146 Herrmann WM, Beach RC: Experimental and clinical data indicating the psychotropic properties of progestogens. Postgaduate Med J 1978:

54(supp.2):82-87. 